\title{
Engineering Bureaucracy: The Genesis of Formal Policies, Positions, and Structures in High-Technology Firms
}

\author{
James N. Baron \\ Stanford University \\ M. Diane Burton \\ Harvard University \\ Michael T. Hannan \\ Stanford University
}

This article examines the impact of organizational founding conditions on several facets of bureaucratization-managerial intensity, the proliferation of specialized managerial and administrative roles, and formalization of employment relations. Analyzing information on a sample of technology start-ups in California's Silicon Valley, we characterize the organizational models or blueprints espoused by founders in creating new enterprises. We find that those models and the social composition of the labor force at the time of founding had enduring effects on growth in managerial intensity (i.e., reliance on managerial and administrative specialists) over time. Our analyses thus provide compelling evidence of path dependence in the evolution of bureaucracy-even in a context in which firms face intense selection pressures - and underscore the importance of the "logics of organizing" that founders bring to new enterprises. We find less evidence that founding models exert persistent effects on the formalization of employment relations or on the proliferation of specialized senior management titles. Rather, consistent with neo-institutional perspectives on organizations, those superficial facets of bureaucracy appear to be shaped by the need to satisfy external gatekeepers (venture capitalists and the constituents of public corporations), as well as by exigencies of organizational scale, growth, and aging. We discuss some implications of these results for efforts to understand the varieties, determinants, and consequences of bureaucracy.

\footnotetext{
A previous draft of this article was presented at the conference "Bureaucracy: Issues and Apparatus," April 3-5, 1998, Marconi Center, Marshal, California. Direct all correspondence to James N. Baron, Graduate School of Business, Stanford University, Stanford, CA 94305-5015 (baron_james@gsb.stanford.edu). This research was supported by the Stanford Graduate School of Business (particularly the Center for Entrepreneurial Studies) and the Alfred P. Sloan Foundation. J. Baron also received generous support from a Marvin Bower Fellowship at Harvard Business School while conducting this research, and $M$. Hannan was supported by the Stanford Graduate School of Business Faculty Trust. We thank Christine Beckman, Robert Gibbons, Rakesh Khurana, Josh Lerner, Craig Olson, and Todd Zenger for useful assistance, comments, and advice.
} 


\section{Introduction}

To many observers, a prominent feature of bureaucracy-if not one of its defining attributes-is its staying power. As Weber (1946:228) noted, "once it is fully established, bureaucracy is among those social structures which are the hardest to destroy." The very term conjures up images of sedentary formal structures, roles, policies, and procedures. But to the extent that the image is apt, this stability poses some potential difficulties for scholars interested in understanding the origins, functioning, and effects of bureaucratic hierarchies. Chief among these is the problem of survivor bias. Our knowledge about bureaucracy is based almost entirely on quantitative and ethnographic studies of long-lived bureaus and enterprises. But it is perilous to make inferences about the genesis of bureaucracy or its defining elements or its effects in different types of environments, based on analyses only of those bureaucracies in a given sector that have managed to endure the longest.

Moreover, research designs that seek to relate present-day features of bureaucracies to particular external and internal contingencies facing organizations may fall short of the mark because of the path-dependent nature of organizational development. Two often-overlooked potential sources of path dependence in the evolution of organizations are the enduring imprint of founder(s) and of the social capital that existed among key early members of the enterprise-their social composition and social relations. Scholars of bureaucracy have emphasized its impersonality and universalism as well as its inevitability. However, work in organizational sociology suggests that the amount, form, and timing of bureaucratization as organizations grow and age often owes a great deal to their founding histories and the "embedded" social relations that existed among early members (Boeker, 1988; Granovetter, 1985, 1995). Indeed, in his seminal treatment of bureaucracy, Weber conjectured that the form and character of bureaucratic institutions depends on the preexisting foundations of authority (charismatic, traditional, or rational-legal) and on the social and economic context, requiring that we understand in each case the particular path through which rationalization and formalization occurred.

Economists and political scientists seem more inclined to concede that organizational evolution reflects path dependence and social relations when the enterprises involved are not-for-profit entities, thought to confront less potent selection pressures, rather than profit-seeking companies in competitive business environments. Yet we suspect path dependence and social influences on organizational forms are also influential in contexts characterized by intense market competition. Scholars, practitioners, and policymakers interested in understanding bureaucracy and its effects can ill afford to ignore the social paths through which bureaucratization emerges in the first place.

To study these issues requires somewhat different research strategies than those customarily adopted by scholars interested in bureaucracy. These new strategies must pay greater attention to how the process of bureaucratization is influenced by the environment at the time of founding, key choices made by organizational architects in the early days of the enterprise, and the social relations among key actors who launch new organizations. In this article, we 
summarize some of our ongoing research along these lines, which draws on a rich archive of data we have assembled on the early histories of a sample of technology companies in California's Silicon Valley [for details on the sample and data collection methods, see Baron, Burton, and Hannan (1996); Baron, Hannan, and Burton (1998); and Burton et al. (1998)]. We document some important ways in which differences in the amount and type of bureaucratization appear to be programmed into organizations very early in their development.

In this article, we focus on several attributes of organizations that scholars have identified as defining aspects of the bureaucratic form. Scott (1992:40) defines bureaucracy "as the existence of a specialized administrative staff." Weber's (1946) classic treatment of modern bureaucracy emphasized several quintessential elements: formal definition (and increasing specialization) of "fixed and official jurisdictional areas"; reliance on hierarchical authority vested in formal roles; formalization and documentation of rules; selection of personnel based on qualifications; employment viewed as a career and governed by explicit and well-documented rules and procedures; and the emergence of management and administration as a "role," conducted full-time as a professional vocation, which is discharged universalistically and dispassionately [see Scott (1992:40-41)]. Accordingly, our empirical analyses focus on three dimensions of bureaucratization: managerial-administrative intensity (the prevalence of specialized managerial and administrative functions and personnel); the formalization of employment policies; and the proliferation of senior management roles that are differentiated with respect to function and/or rank.

The main findings from those analyses are worth summarizing at the outset:

Founders of technology companies embrace quite distinct "organizational blueprints" or conceptions about employment relations. These blueprints vary, among other respects, in how strongly they presume that control and coordination will be effected through the standard devices of bureaucratic administration-rules, procedures, reporting relations, specialization of tasks, performance evaluation, and the like - rather than through informal, tacit means of generating commitment or through personal oversight by the founders themselves or their agents. We observe clear differences in models or blueprints even between firms competing in the same particular industry niches and claiming to pursue similar business strategies.

These blueprints profoundly shape the extent (and speed) of some aspects of formalization and bureaucratization in firms over their early years, even controlling for other features of organizations and their environments likely to influence organizational design. Indeed, the current level of managerial and administrative intensity in these enterprises is more strongly related to the founder's espoused organizational blueprint than it is to the contemporaneous organizational models embraced by the current CEO. We find that founders' early premises about employment relations exert enduring effects on the managerial-administrative intensity of the organizations they build, even when/after the initial founder(s) departs.

However, we find less evidence that founding models exert persistent effects on the formalization of employment relations or the proliferation of special- 
ized senior management titles. Consistent with neo-institutional perspectives on organizations, those superficial facets of bureaucracy appear to be shaped more by the need to satisfy external gatekeepers (venture capitalists and the constituents of public corporations) and by exigencies of organizational scale, growth, and aging.

Preliminary evidence suggests that patterns of bureaucratization and formalization are also influenced by the social composition of the workforce (specifically, in our sample, the gender mix) early in a firm's history. These findings suggest that applying such terms as "organizational architects" and "blueprints for organizing" to founders and their activities in building new enterprises may be particularly apt. Like architects, founders of organizations appear to design structures that depend on the social characteristics of, and relations among, the individuals intended to occupy the structure.

After describing the set of firms we have been studying, we summarize these and other findings to date from our project that bear on the process of bureaucratization. We then sketch some implications for theory and research on the varieties, genesis, and consequences of bureaucracy.

\section{The Context}

The Stanford Project on Emerging Companies (SPEC) is a panel study of more than 170 young, high-technology firms in California's Silicon Valley. ${ }^{1}$ This project seeks to understand how founding conditions and early decisions affect subsequent organizational evolution, which necessitates information about the earliest days of the organization. We assumed that individuals could only reliably recall fairly recent information; we therefore limited the sample to firms no more than 10 years old when first visited by our research team (in 1994 1995). ${ }^{2}$ The project also seeks to understand how human resource systems are established. We assumed that organizations need to be of a minimum size before facing a need for any formal systems or practices; accordingly, firms in

1. In 1994, 250 companies were sent a letter soliciting their participation in the study. These firms were selected out of 676 technology firms having more than $10 \mathrm{employecs}$, according to two commercial databases on Silicon Valley technology companies: Rich 's Everyday Sales Prospecting Guide (1994) and the Technology Resource Guide to Greater Silicon Valley (1993/4), published by Corptech. The 250 firms were selected according to a stratified sampling plan described in Baron, Burton, and Hannan (1996:Figure 1). Of the 250 firms to whom we originally wrote (some of which had gone out of business, moved out of the area, or were acquired by the time we contacted them), 109 eventually agreed to take part in the study. Utilizing the same sampling frame, we contacted an additional 94 companies in 1995 (out of 168 that werc added to the 1995 edition of the CorpTech directory), 42 of which agreed to be studicd. Finally, we supplemented the sample by contacting 32 very young firms not listed in the CorpTech directory, which were identified by tracking the Silicon Valley business press; 22 of these firms participated in the study. We were concerned that relying exclusively on guidebooks such as Rich's and CorpTech to construct the sampling frame might underrepresent new start-ups in our study, given that there sometimes appear to be considerable time lags before newly created firms are listed in those guidebooks [for additional details regarding sampling and methods, see Burton, Hannan, and Baron (1998)].

2. A few firms eventually included in the study had commenced operations in some form or another more than 10 years before the initial visit from our research team. 
our study needed to have at least 10 employees by the time they were sampled. By focusing on firms in a single region and sector of economic activity, we control for a number of labor market and environmental conditions that may be relevant to organizational design.

Data on each firm were gathered through a combination of survey, interview, and archival methods (Burton, 1995). In 1994-1995, trained MBA and doctoral students conducted semistructured interviews with at least one founder, the current chief executive officer (CEO), and a key informant whom the CEO nominated to provide information about human resource practices. Informants about company history and human resource management were also asked to complete surveys and return them to us prior to being interviewed. The company history survey solicited details about the firm's founding and subsequent milestones. The human resource management survey sought longitudinal information about workforce demographics and a variety of employment policies and practices. Information from the surveys was used to guide interviews with the three informants and was then coded into formats amenable to quantitative data analysis.

Founders were queried about how they had thought about the organizationbuilding process and about employment relations, including whether or not they had "an organizational model or blueprint in mind when ... founding the company." Probes were used in the interviews to try and pinpoint the key features or assumptions of this model and where it came from. ${ }^{3}$ CEOs were asked a parallel set of questions about the present. Responses obtained from those interviews were content analyzed and coded to develop a typology of organizational blueprints within our sample of companies [for additional details, see Burton, Hannan, and Baron (1998)].

As background for the results we summarize, Table 1 provides some descriptive information on the companies in our sample. ${ }^{4}$

\section{Models of Organizing in Young Technology Firms}

A large fraction of the founders and chief executives we interviewed indicated that they had a specific organizational model in mind, often patterned to reflect- or diverge from-a particular firm with which they had prior experience. Content analyses of transcripts from these interviews suggested that their organizational models reflect a set of interrelated premises about three

\footnotetext{
3. Founders were thus asked retrospectively about their model at the time they were building the organization. We consider the possibility of selective retrospection below (also see Baron, Hannan, and Burton, 1998).

4. Table 1 provides descriptive statistics on all firms in the sample for which each variable was available, whereas the various statistical analyses summarized below are based on subsets of the total sample due to listwise deletion of cases with missing data. Not surprisingly, we had less difficulty collecting data conceming present-day staffing patterns and occupational and gender composition than we did in gathering comparable data for the firm's first year of operations. Conscquently, in analyses examining the effects of carly labor force variables on subsequent outcomes, the sample available for analysis is considerably smaller. [For details regarding patterns of missing data, sec Baron, Hannan, and Burton (1998:Appendix).]
} 
Table 1. Descriptive Statistics on SPEC Firms

\begin{tabular}{|c|c|c|c|c|c|c|}
\hline Variables & Valid $N$ & Mean & Median & Std. Dev. & Min & $\operatorname{Max}$ \\
\hline $\begin{array}{l}\text { Total employees (FTEs), } \\
1994\end{array}$ & 102 & 161.226 & 72.500 & 270.819 & 6.00 & 1895.00 \\
\hline $\begin{array}{l}\text { Total employees (FTEs), } \\
\quad \text { year } 1\end{array}$ & 83 & 28.169 & 14.000 & 63.147 & 1.00 & 440.00 \\
\hline $\begin{array}{l}\text { Managers/administrators } \\
\text { (FTEs), } 1994\end{array}$ & \multicolumn{5}{|c|}{ Managers/administrators } & 618.00 \\
\hline $\begin{array}{l}\text { Managers/administrators } \\
\text { (FTEs), year } 1\end{array}$ & 80 & 7.569 & 5.000 & 13.248 & 1.00 & 98.00 \\
\hline \multicolumn{6}{|l|}{ Proportion female } & 0.77 \\
\hline $\begin{array}{l}\text { Proportion female } \\
\text { employees, year } 1\end{array}$ & 83 & 0.228 & 0.212 & 0.156 & 0.00 & 0.64 \\
\hline \multicolumn{6}{|l|}{ Proportion science/ } & 0.76 \\
\hline $\begin{array}{l}\text { Proportion sales/ } \\
\text { marketing, } 1994\end{array}$ & 101 & 0.147 & 0.121 & 0.119 & 0.00 & 0.52 \\
\hline $\begin{array}{l}\text { Proportion clerical, } 1994 \\
\text { Proportion science/ }\end{array}$ & 101 & 0.058 & 0.053 & 0.052 & 0.00 & 0.27 \\
\hline $\begin{array}{l}\text { engineering, year } 1 \\
\text { Proportion sales/ }\end{array}$ & 81 & 0.378 & 0.421 & 0.232 & 0.00 & 0.78 \\
\hline $\begin{array}{l}\text { marketing, year } 1 \\
\text { Proportion clerical. }\end{array}$ & 80 & 0.077 & 0.053 & 0.099 & 0.00 & 0.43 \\
\hline year 1 & 80 & 0.039 & 0.000 & 0.061 & 0.00 & 0.29 \\
\hline Organizational age, 1994 & 173 & 6.144 & 6.083 & 2.825 & 0.58 & 14.58 \\
\hline $\begin{array}{l}\text { Firm received venture } \\
\text { capital by } 1994\end{array}$ & 164 & 0.701 & & & 0.00 & 1.00 \\
\hline $\begin{array}{l}\text { Firm went public } \\
\text { by } 1994\end{array}$ & 173 & 0.376 & & & 0.00 & 1.00 \\
\hline $\begin{array}{l}\text { Founder was still CEO } \\
\text { in } 1994\end{array}$ & 150 & 0.593 & & & 0.00 & 1.00 \\
\hline $\begin{array}{l}\text { Employment growth (\%) } \\
\text { from year } 1 \text { to } 1994\end{array}$ & 82 & 1033.685 & 346.429 & 1742.455 & -55.00 & 11743.75 \\
\hline $\begin{array}{l}\text { Human resources } \\
\text { employees, } 1994\end{array}$ & 101 & 2.585 & 1.000 & 5.903 & 0.00 & 56.00 \\
\hline $\begin{array}{l}\text { Founder model: } \\
\text { autocratic }\end{array}$ & 154 & 0.065 & & & 0.00 & 1.00 \\
\hline $\begin{array}{l}\text { Founder model: } \\
\text { bureaucratic }\end{array}$ & 154 & 0.058 & & & 0.00 & 1.00 \\
\hline $\begin{array}{l}\text { Founder model: } \\
\text { commitment }\end{array}$ & 154 & 0.130 & & & 0.00 & 1.00 \\
\hline $\begin{array}{l}\text { Founder model: } \\
\text { engineering }\end{array}$ & 154 & 0.325 & & & 0.00 & 1.00 \\
\hline $\begin{array}{l}\text { Founder model: } \\
\text { star }\end{array}$ & 154 & 0.097 & & & 0.00 & 1.00 \\
\hline $\begin{array}{l}\text { Founder model: } \\
\text { hybrid }\end{array}$ & 154 & 0.325 & & & 0.00 & 1.00 \\
\hline
\end{tabular}




\begin{tabular}{|c|c|c|c|c|c|c|}
\hline Variables & Valid $N$ & Mean & Median & Std. Dev. & Min & Max \\
\hline $\begin{array}{l}\text { CEO model: } \\
\text { autocratic }\end{array}$ & 155 & 0.077 & & & 0.00 & 1.00 \\
\hline CEO model: & & & & & & \\
\hline $\begin{array}{l}\text { bureaucratic } \\
\text { CEO model: }\end{array}$ & 155 & 0.200 & & & 0.00 & 1.00 \\
\hline $\begin{array}{l}\text { commitment } \\
\text { CEO model: }\end{array}$ & 155 & 0.084 & & & 0.00 & 1.00 \\
\hline $\begin{array}{l}\text { engineering } \\
\text { CEO model: }\end{array}$ & 155 & 0.258 & & & 0.00 & 1.00 \\
\hline $\begin{array}{l}\text { star } \\
\text { CEO model: }\end{array}$ & 155 & 0.084 & & & 0.00 & 1.00 \\
\hline hybrid & 155 & 0.297 & & & 0.00 & 1.00 \\
\hline $\begin{array}{l}\text { Industry: computer hardware/ } \\
\text { software }\end{array}$ & 173 & 0.480 & & & 0.00 & 1.00 \\
\hline $\begin{array}{l}\text { Industry: manufacturing } \\
\text { Industry: medical devices/ }\end{array}$ & 173 & 0.052 & & & 0.00 & 1.00 \\
\hline biotechnology & 173 & 0.139 & & & 0.00 & 1.00 \\
\hline Industry: research & 173 & 0.023 & & & 0.00 & 1.00 \\
\hline Industry: semiconductors & 173 & 0.104 & & & 0.00 & 1.00 \\
\hline $\begin{array}{l}\text { Industry: telecommunications/ } \\
\text { networking }\end{array}$ & 173 & 0.202 & & & 0.00 & 1.00 \\
\hline $\begin{array}{l}\text { Founding strategy: } \\
\text { technical innovation }\end{array}$ & 161 & 0.491 & & & 0.00 & 1.00 \\
\hline $\begin{array}{l}\text { Founding strategy: } \\
\text { technical enhancement } \\
\text { Founding strategy: }\end{array}$ & 161 & 0.205 & & & 0.00 & 1.00 \\
\hline $\begin{array}{l}\text { marketing-based } \\
\text { Founding strategy: }\end{array}$ & 161 & 0.137 & & & 0.00 & 1.00 \\
\hline $\begin{array}{l}\text { hybrid } \\
\text { Founding strategy: }\end{array}$ & 161 & 0.099 & & & 0.00 & 1.00 \\
\hline cost & 161 & 0.068 & & & 0.00 & 1.00 \\
\hline $\begin{array}{l}\text { Human resources } \\
\text { formalization, } 1994\end{array}$ & 104 & 6.644 & 6.500 & 2.281 & 0.00 & 11.00 \\
\hline $\begin{array}{l}\text { Human resources } \\
\text { formalization, year } 1\end{array}$ & 104 & 0.981 & 0.000 & 1.790 & 0.00 & 9.00 \\
\hline $\begin{array}{l}\text { Specialized senior management } \\
\text { titles, } 1994\end{array}$ & 166 & 4.488 & 4.000 & 3.448 & 0.00 & 15.00 \\
\hline $\begin{array}{l}\text { Specialized senior management } \\
\text { titles, year } 1\end{array}$ & 166 & 1.331 & 1.000 & 1.631 & 0.00 & 8.00 \\
\hline
\end{tabular}

Medians and standard deviations not shown for binary variables. Variables for founder and CEO models combine "pure" and "quasi-pure" types (see text for explanation). "Human resources formalization" measures presence of 11 HR policies and practices (see lext). "Senior management titles" measures presence of up to 18 functional and rank distinctions among senior management (see text for explanation). "Year 1" variables pertain to firm's first year of operations; "1994" variables pertain to first visit to each firm, which was in 1994-1995.

dimensions of the employment relationship:

1. Attachment. Is the primary intended basis of employee attachment and retention: (a) monetary rewards (money); (b) opportunities for challeng- 
Table 2. Five Pure-Type Employment Models in Young Technology Companies, Based on Three Dimensions

\begin{tabular}{|c|c|c|c|}
\hline \multicolumn{3}{|c|}{ Dimensions } & \multirow[t]{2}{*}{ Employment Model } \\
\hline Attachment & Selection & Coordination/Control & \\
\hline Work & Potential & Professional & Star \\
\hline Work & Skills & Peer/cultural & Engineering \\
\hline Love & Fit & Peer/cultural & Commitment \\
\hline Work & Skills & Formal & Bureaucracy \\
\hline Money & Skilis & Direct & Autocracy \\
\hline
\end{tabular}

ing work and professional development (work); or (c) a strong emotional bond to the organization and its members (love)?

2. Basis of control. Is control and coordination of work to be achieved principally through: (a) direct oversight; (b) formal rules, systems, and procedures; (c) informal mechanisms (peers or organizational culture), or (d) professionalism? (Founders did not typically refer to "professionalism" explicitly, but some founders took for granted that workers were committed to excellence in their work and could perform at high levels with considerable autonomy because they had been professionally socialized to do so. Not surprisingly, this model tends to be accompanied by an emphasis on recruitment of high-potential individuals from elite institutions.)

3. Selection. Was the primary consideration in selecting employees to be: (a) their command of specific skills necessary to perform welldefined and immediately needed tasks effectively; (b) the potential to perform effectively on a series of projects (often not yet even envisioned) through which the employee would move over time; or (c) values and organizational fit?

Founders' premises can thus be classified into three types of attachment, three types of selection, and four types of control, yielding $3 \times 3 \times 4=36$ possible combinations. In previous work we have identified five basic types of organizational models derived from the interview responses we received from founders of the technology companies we studied. Specifically, Burton, Hannan, and Baron (1998) have shown that the observations clustered into a few cells, corresponding to what they term pure-type employment models. These are displayed in Table 2.

The engineering model involves attachment through challenging work, peer group control, and selection based on specific task abilities. This is generally thought to represent the default blueprint for a high-tech Silicon Valley start-up (Saxenian, 1994), and it is the most prevalent model among the SPEC founders (espoused by roughly a third of them; see Table 1). The star model presumes attachment based on challenging work, reliance on autonomy and professional control, and selection of elite personnel based on their long-term potential. The commitment model is characterized by emotional or familial attachments 
to the organization, selection based on values or fit, and peer group control. The bureaucracy model involves attachment based on providing challenging work and/or opportunities for development, selection based on qualifications for a particular role, and formalized control. Finally, the autocracy model is premised on monetary motivations, control and coordination through direct oversight, and employees who are selected to perform prespecified tasks.

The majority of firms can be classified into one of these five ideal-type categories. (A number of the remaining firms are close to one-and only one- of these pure types, and we call these quasi-pure types. $)^{5}$ In previous work, we have shown that founders' models are related to various facets of organizational development, including the odds of going public, the likelihood of the founder being replaced by a new CEO, the speed with which a full-time HR manager is hired, and the likelihood (and speed) of adopting various HR practices (see Baron, Burton, and Hannan, 1996; Hannan, Burton, and Baron, 1996). ${ }^{6}$

\section{Formalization and Bureaucratization in Young Technology Firms: Patterns and Determinants}

4.1 Effects of Founders' Models on Managerial and Administrative Intensity We begin by summarizing several key results from a recent paper (Baron, Hannan, and Burton, 1998), which examined how the founder's espoused or implicit organizational model influences the extent of managerial-administrative intensity in the firm. We measured managerial-administrative intensity as the number of full-time equivalent (FTE) managerial and administrative specialists, controlling for the number of other (full-time equivalent) employees in the firm as well as other attributes of the enterprise likely to influence the extent of bureaucratization.

Managerial-administrative intensity is a useful summary measure of the tendency toward bureaucratization, inasmuch as the predominance of managerial and administrative specialists in organizations (i.e., bureaucrats) is arguably the sine qua non of bureaucracy. It is an interesting dependent variable to explore for several other reasons as well. First, organizations are themselves paying increasing attention to managerial and administrative overhead, given its putative effects on costs, flexibility, and the speed and costs of decisions. ${ }^{7}$

5. For purposes of the analyses reported in this article, they are grouped together with the purc type which they resemble most. This mutes the contrasts slightly among catcgories, but it provides greater statistical power by increasing the number of observations in several of the categorics.

6. Results reported in these articles were based on the first subset of 100 companies in which we gathered data and employed a slightly different typology of employment models, with four rather than five categories.

7. Indeed, some organizations explicitly monitor and report on the proportion of their workforce in managerial positions and other indicators of administrative overhead as part of a "balanced scorecard" approach to tracking their intangible assets. One such company is Skandia Assurance and Financial Services, a subsidiary of Skandia Insurance Company, a Sweden-based company offering insurance and financial services worldwide. Skandia vicws this measure as an indicator of their success at reducing overhead through self-management (see Edvinsson and Malone, 1997). 
Second, whereas one might be concerned that founders' responses concerning their organizational blueprints were retrospective, our measure of administrative overhead is derived from a staffing grid showing employment by occupation at the end of the first year of operations and in 1994-1995, filled out for our project by the person overseeing HR in each company. Hence, it seems unlikely that any net differences in managerial and administrative staffing patterns as a function of founders' models can be attributed to selective retrospection by the participants in our study.

We estimated multivariate regressions relating the $(\log )$ number of managerial and administrative FTEs in 1994-1995 to dummy variables corresponding to the founder's organizational model, controlling for the $(\log )$ number of nonmanagerial, nonadministrative FTEs in 1994-1995, as well as other factors that might influence bureaucratization, including occupational composition, industry, strategy, firm age, whether the firm ever went public and/or received venture capital, growth, executive succession, and the level of managerial and nonmanagerial employment observed at the end of the firm's first year of operations. $^{8}$

Our clearest hypothesis concerns the contrast between firms founded along bureaucratic versus commitment lines. It has often been claimed that by relying on implicit and informal controls and aligning the interests of the firm with those of its workers through long-term attachments, organizations structured along clan or commitment lines can economize on bureaucratic overhead (Walton, 1985). In contrast, we expect that firms whose founders initially espoused a bureaucratic model would, at a given age and scale, exhibit the greatest reliance on managerial and administrative specialists. ${ }^{9}$ For our purposes here, it suffices to note that we expected the remaining categories to lie in between these extremes.

As hypothesized, we found that the bureaucracy and commitment models were at the opposite extremes in terms of managerial intensity. Firms whose founders championed a bureaucratic model had significantly more managerial and administrative specialists by 1994-1995, all else being equal, than otherwise comparable firms whose founder had espoused any of the other four models. At the other end of the spectrum, commitment firms were significantly less administratively intense than otherwise comparable firms founded according to any other model (with the exception of star firms, where the contrast was not statistically significant). ${ }^{10}$

8. Estimates were obtained using weighted least squares techniques to correct for heteroskedasticity; not surprisingly, the error variance typically diminished with firm size, so observations werc weighted as a function of log employment in 1994-1995 (sce Baron, Hannan, and Burton, 1998).

9. Note that there is nothing definitional here to require an association between founders' premises regarding coordination and control and the actual extent of burcaucratization observed. For instance, founders might have envisioned controlling employees by relying extensively on budgets, information systems, or other formal means, which conccivably could have reduced the need for managerial oversight or some other aspects of burcaucracy.

10. In a regression predicting the (log) number of manager-administrator FTEs, the coefficients associated with each model (relative to the omitted category of burcaucracy) werc star, -0.807 ; 
Table 3. Predicted Differences in the Managerial and Administrative Component as a Function of the Founder's Organizational Model ${ }^{a}$

\begin{tabular}{|c|c|c|c|c|}
\hline \multirow[b]{3}{*}{$\begin{array}{l}\text { Number of } \\
\text { Nonadministrative } \\
\text { Employees }\end{array}$} & \multicolumn{4}{|c|}{ Founder's Organizational Model } \\
\hline & \multicolumn{2}{|c|}{ Commitment } & \multicolumn{2}{|c|}{ Bureaucracy } \\
\hline & $\begin{array}{l}\text { Number of } \\
\text { Managers and } \\
\text { Administrators }\end{array}$ & $\begin{array}{c}\text { Percent of } \\
\text { Total } \\
\text { Employment }^{b}\end{array}$ & $\begin{array}{c}\text { Number of } \\
\text { Managers and } \\
\text { Administrators }\end{array}$ & $\begin{array}{c}\text { Percent of } \\
\text { Total } \\
\text { Employment }^{b}\end{array}$ \\
\hline 50 & 11.1 & $18.2 \%$ & 29.9 & $37.5 \%$ \\
\hline 150 & 26.9 & $15.2 \%$ & 72.4 & $32.6 \%$ \\
\hline 500 & 79.9 & $13.8 \%$ & 214.7 & $30.0 \%$ \\
\hline 1500 & 207.5 & $12.2 \%$ & 557.8 & $27.1 \%$ \\
\hline
\end{tabular}

a Based on coefficients reponted in Baron, Hannan, and Burton (1998: Table 3, model 2)

$b$ Full-time managerial and administrative personnel as percentage of the firm's full-time labor force

To illustrate the large magnitude of these effects, Table 3 reports the number of full-time managers and administrators in 1994-1995 predicted by our regression model for two firms of equal size, differing only in being founded along commitment versus bureaucracy lines.

Recall (from Table 1) that the median firm in our sample was only about 6 years old when first visited by our research team in 1994-1995 (the date to which our dependent measure of managerial and administrative employment pertains). That firms already differ so dramatically in the prevalence of managerial and administrative specialists based on the founder's initial blueprint is quite striking. But should we necessarily construe these results as evidence of path dependence? Clearly there are other potential interpretations one might apply to these results. Moreover, despite the fact that our dependent variable is an objective measure usually obtained from someone other than the individual whose responses were the basis for coding the founder's model, the issue of potential retrospection bias still deserves scrutiny.

Among the control variables, employment size and having gone public were the strongest determinants of administrative intensity, both increasing the level and growth of managerial overhead. Administrative intensity was also somewhat higher in firms pursuing a marketing-oriented strategy, presumably reflecting the greater overhead entailed by strategies emphasizing marketing, sales, and customer service.

The effects of founders' employment models on administrative intensity persist despite these and many other controls, however. Various supplementary analyses bolster our confidence in these results and in the view that they reflect

commitment, -0.989 ; autocracy, -0.427 ; cngincering, -0.684 ; and "hybrid," -0.646 . (The "hybrid" catcgory captures firms that did not fit into any single pure- or quasi-pure type based on the three dimensions.) These coefficients imply that relative to bureaucracies, otherwise comparable firms founded along commitment lines have about $e^{-0.989}=37 \%$ as many full-time managers and administrators in 1994-1995, star firms about $45 \%$ as many, and the remaining categories of firms roughly 50 to $65 \%$ as many. The regression model explains $90.6 \%$ of the observed variance $(88.7 \%$ after adjusting for degrees of freedom). 
path-dependent development. For instance, we added controls for managerial intensity (and for total nonadministrative employment) at the end of the first year. These controls do not significantly alter the pattern of effects. This provides a fairly stringent test of the enduring effects of founders' models on bureaucratization, because these analyses effectively control for any unmeasured attributes of firms that affected their initial scale and their early reliance on specialized managerial-administrative personnel, focusing instead on whether the models result in different trajectories of bureaucratization over time. Nor did controls for employment growth over time, having received venture capital, or replacing the founder with a new $\mathrm{CEO}$ yield significant effects on administrative intensity or alter the basic pattern of results.

We also conducted analyses in which we replaced the vector of dummy variables characterizing the founder's organizational model with equivalent indicator variables reflecting the model of the CEO whom we interviewed in 1994-1995. (This was a different person than the founder in $41 \%$ of the firms; when interviewing founder-CEOs, we asked a parallel series of questions about their employment model and assumptions for the present-day period-19941995-as we had asked them about the initial founding period.) As a group, the vector of dummy variables characterizing the CEO's organizational model does not have a statistically significant effect on managerial and administrative intensity in 1994-1995; moreover, adding measures depicting the CEO's model does not reduce either the magnitude or significance of the effects associated with the founder's model. In other words, it is apparently how the founder initially conceptualized the organization at its inception, not how the then-CEO (who was often a founder) conceived of it, that predicts bureaucratization in 1994-1995. We construe this result as providing quite compelling evidence of path-dependent development.

One additional set of supplementary analyses we undertook deserves brief mention. Recall that the typology of employment models is derived from three dimensions: attachment, selection, and coordination/control, which differentiates firms whose founders intended to coordinate employee effort through formal rules, procedures, and systems from those whose founders espoused direct oversight, informal mechanisms, or professionalism. One might ask whether any association between employment models and bureaucratization simply reflects the control dimension. To examine that issue, we estimated specifications that replaced the binary variables denoting the model types (autocracy, engineering, star, commitment, and bureaucracy) with seven dummy variables denoting the different responses possible on each of the three dimensions that underlie the models. " Not surprisingly, of the three dimensions, the

\footnotetext{
11. For instance, two dummy variables - corresponding to attachment based on money and love, with "work" as the omitted category - were used to represent the attachment dimension. Similarly, two dummy variables were used to represent the three possible responses on selection, and three dummics were used to capture the four potential bases of coordination and control. Hence, a total of scven dummy variables are required to represent all 36 possible response profiles along the three dimensions. For details, see Baron, Hannan, and Burton (1998).
} 
one pertaining to coordination/control has the strongest relationship to managerial intensity: firms in which the founder embraced normative, professional, or direct control all display somewhat lower levels of managerial intensity than do firms in which the founder espoused reliance on formal control. However, of the seven effects required to characterize firms along the three dimensions, only the contrast between direct and formalized control was statistically significant at the .05 level, with firms embracing direct control being less managerially intense ( $b=-0.498, p=.033)$ As one would expect, firms emphasizing cultural fit in selection were also somewhat less administratively intense than firms intending to select based on specific competencies $(b=-0.251, p=.089)$. But taken as a group, the seven dummy variables representing firms' locations along the three dimensions do not contribute much in seeking to explain variation in managerial-administrative intensity $(F=1.545, p=.17)$. In short, the five employment model types are considerably more parsimonious and more powerful than the dimensions in accounting for differences in administrative intensity, which indicates that it is the interactions among dimensions, rather than an organization's position on each individual dimension, that influence this facet of bureaucratization. This result provides additional validation for the notion that our typology captures qualitatively distinct models of organizing at the inception of firms, which have enduring consequences.

\subsection{Social Bases of Organizational Structure: Gender Composition and Managerial In- tensity}

In designing physical structures, architects devote considerable attention to the characteristics (social and otherwise) of the expected occupants. As sociologists, we think it no less plausible that the architects of social structures attend to the social characteristics of the intended occupants in the process of designing and building organizational forms. Previous research has documented, for instance, how the design and valuation of job titles is shaped by the social composition of the individuals who initially occupy those roles [for an overview, see Baron and Pfeffer (1994)]). We were interested in whether the same is true for the design of organizational structures. Consequently, we sought to explore whether the pace of bureaucratization depends on the social composition of the workforce at the firm's inception. Aside from information on occupational composition, the only demographic information we had at multiple points in time was the gender composition of the labor force, so we examined its effect on managerial intensity. [For an overview of competing hypotheses, see Baron, Hannan, and Burton (1998)].

We found that women's proportional representation in the labor force at the end of the firm's first year of operations had a statistically significant negative effect on managerial-administrative intensity, even controlling for founder's model, industry, strategy, organizational age, and whether the firm had gone public. Supplementary analyses revealed the effect to be fairly robust, holding up in the presence of controls for numerous other attributes of these companies that might be expected to covary with gender mix: occupational composition (both at the end of the first year and in 1994-1995); CEO succession; reliance 
on independent contractors; use of outsourcing for various administrative functions; formalization of HR practices within the first year and over time; size, growth, and structure of the human resources function; and the presence of women within senior management at the firm's inception.

Our results imply fairly dramatic differences in administrative intensity for firms of a given size by 1994-1995, based on women's proportionate representation in the first year. For example, consider two otherwise equivalent firms-both founded along bureaucratic lines and each having 50 nonadministrative FTEs in 1994-1995, but one staffed entirely by men in its first year and the other having a workforce that was $50 \%$ female at the end of the first year. Our statistical results imply that the former firm would have had 29.9 full-time managers and administrators by 1994-1995, compared to 18.6 for the latter. At a scale of 500 nonadministrative employees, the corresponding contrast is 214.7 versus 133.1 managerial and administrative FTEs, respectively; at 1500, the contrast is 557.8 versus 345.7 . As we found in contrasting the effects of founders' versus CEOs' organizational models, early workforce demography was more decisive than the current state of affairs - that is, the present-day gender mix was less relevant to current managerial intensity than was the gender mix at the firm's inception. ${ }^{12}$

Although exploratory, these results suggest that organizational architecture is shaped by social characteristics of, and relations among, the early "occupants" of the structures being designed. We believe the negative effects of women's early representation in the SPEC firms on the specialization of managerial and administrative roles reflects two influences. First, previous research has documented that organizations are more likely to proliferate idiosyncratic job titles, which enhance the status and skill monopoly of their incumbents, for men than for women (Baron and Pfeffer, 1994). At such an early point in the history of these firms, we suspect that there is rather little variation in the amount of management and administration to be done as a function of gender composition, particularly given that we are controlling for size, industry, occupational mix, and the like. Rather, we believe our findings reflect a greater tendency to define those who are managing and administering as "managers" and "administrators" when they are male than when they are female. (Evidence reported below concerning the effects of initial gender mix on the early proliferation of senior management titles is also consistent with this interpretation; see Table 5).

Detailed examination of some of the extreme cases suggested a second process may be at work in producing the effects of gender mix on managerial intensity. When we examined which SPEC firms had the highest representation of female employees early, we found this outcome tended to be an indirect result of network-based recruitment strategies. In some cases the founders

12. If gender composition in year $I$ is replaced by a measure for 1994-1995, the effect is negative but only marginally significant $(b=-1.010, t=-1.772)$. If measures for both time points are included simultaneously, the effect for time 1 declines slightly in magnitude and statistical significance $(b=-0.776, t=-1.897)$ but still dwarfs the effect for 1994-1995 $(b=-0.427$, $t=-0.667)$. 
were well established in an industry and drew upon their professional contacts. For example, two early-stage biotechnology firms were founded by scientific teams from established firms. These founders were able to recruit associates from their prior employer to the new venture as well as other colleagues from the industry (or from universities). In other cases, founders relied on people known from their ethnic or religious community, particularly when they were not otherwise in a strong labor market position.

Thus firms in which women were present from the start may have been the ones most likely to be built by relying on personal networks, creating a larger stock of social capital on which founders could draw as an alternative to formalized structures of coordination and control. ${ }^{13}$ Given the social similarities and strong interpersonal connections established through network-based hiring, founders could presumably rely more on peer monitoring and self-management rather than formal means of coordination and control, and this may become institutionalized as firms grow and age. Consistent with this interpretation, supplementary analyses that control for the initial gender mix by occupational category reveal that it is women's early representation within the core scientific and technical occupations that dampens growth in administrative intensity, not their relative share in other kinds of work roles (e.g., clerical or sales). ${ }^{14}$

If these findings and interpretations regarding the effects of gender composition are borne out in future research, they would potentially call into question one of the most basic claims about bureaucracy, namely, that it tends to favor less advantaged groups by enforcing universalistic criteria in recruitment and selection. If women are better represented early on in those technology startups that rely on network-based hiring, this suggests either that (a) the personal connections of founders and others involved in early hiring were more diverse (at least with respect to gender) than the pools of talent to surface through other means of recruitment; or (b) social ties to potential female applicants worked to temper potential sources of gender bias that might otherwise have been more prevalent. This suggests a promising area for future research, namely, examining under what circumstances bureaucratic employment practices may produce less universalistic outcomes than practices that leverage personal ties and preexisting social networks among actors.

\subsection{Effects of Founders' Models on the Formalization of HR Policies and the Proliferation of Senior Management Titles}

To gauge the generality of the patterns we uncovered with regard to managerial intensity, we examined how founders' organizational blueprints affect several other facets of bureaucratization: the formalization and specialization of top management roles, and the adoption of formalized and rationalized employment

13. We were concerned that there might also be male-dominated firms, recruiting extensively through social networks, that are able to economize on specialized administration (relative to the level of managerial intensity one would otherwise predict). However, we were not able to identify any such cases in our samplc.

14. Detailed results are available from authors on request. 
practices. This research is ongoing, but the preliminary results to date are suggestive, so we briefly summarize them below.

4.3.1 Formalization of Human Resource Practices. An important element of bureaucratization concerns the formalization, standardization, and documentation of employment relationships. Accordingly, we examined how founders' organizational models and the firm's early gender mix affected the rate of HR formalization. The survey completed during 1994-1995 by the person in each organization most knowledgeable about HR matters indicated whether (and when) a number of employment practices, policies, forms, and documents were adopted. Eleven of these items seem directed at formalizing, standardizing, and/or documenting employment practices: organization chart; standardized employment application; written job descriptions; personnel manual or handbook; written employment tests; written performance evaluations; standard performance evaluation forms; written affirmative action plans; standard employment contract for exempt employees; employee grievance or complaint forms; and human resources information system. We constructed scales (ranging from 0 to 11) indicating how many of those practices each firm had adopted (a) by the end of its first year of operations, and (b) by the time it was first interviewed by the SPEC research team in 1994-1995.

The descriptive statistics in Table 1 indicate that considerable formalization of human resources practices occurred over time within the sample of SPEC firms. At the end of their first year of operations, firms on average had adopted few, if any, of the 11 practices (mean $=0.98$; median $=0$ ); indeed, $64 \%$ of the firms had not adopted any of these employment practices within their first year of operations, and only $23 \%$ adopted more than one of these employment practices within their first year of operations. In contrast, by the time of the first visit from the SPEC research team, the average firm had adopted between 6 and 7 of the 11 practices (median $=6.5$ ). ${ }^{15}$

We suspected that the fraction of these practices adopted by firms might display the sigmoidal pattern often found in growth and diffusion studies. Consequently, in one form of analysis we modeled these scales by calculating the proportion of the 11 employment practices a firm had adopted (by the end of the first year and by 1994-1995) and applying a probit transformation to attain the desired functional form. Our multivariate analyses controlled for the same

15. In some instances, we knew that a firm had adopted a given HR practice by the time it was visited in 1994-1995, but the precise date of adoption was not known. In those cases, we obviously cannot know whether the practice had been adopted by the end of the first year, and the measure for time 1 formalization reported in Table 1 assumes it was not. Conscquently, in comparing formalization at the end of year 1 versus in 1994-1995 (in Tablc 4b), wc utilized a different measure, which treated a given HR practice as nonexistent in 1994-1995 unless we knew a specific date of adoption, as was done for the measure of year 1 formalization (see footnotes to Tables $4 \mathrm{a}, \mathrm{b})$. Using this alternate measure for $1994-1995$ (mean $=5.58 ;$ median $=6 ; \mathrm{SD}=$ 2.21 ) ensures comparability between the two time points. However, parallel analyses based on the total number of HR practices adopted by 1994-1995 (cven those for which timing information was missing) produced results that did not differ materially from those we report in Table $4 \mathrm{~b}$. 
set of variables that were held constant in the analyses of managerial intensity summarized above. ${ }^{16}$ Because these (untransformed) scales are counts, we also estimated Poisson and negative binomial regressions (Maddala, 1983). The pattern of results obtained was very similar irrespective of the particular specification and method employed (as illustrated in Table 4a, which reports estimates from both the negative binomial and probit regressions for employment formalization in the first year). Consequently, we report only the probit-transformed regression results for employment formalization by 1994-1995 (in Table 4b), noting the few cases where the Poisson estimates differed (see below).

Table $4 \mathrm{a}$ reports analyses predicting the number of formal HR practices adopted within the first year of operations. Neither the count models nor the probit regressions indicate a strong relationship between founders' employment models and the level of employment formalization evident within a firm's first year of operations. Although firms founded as bureaucracies (the omitted category in Table 4a) evidence more formalization than all other types of firms, only companies founded along engineering lines display significantly less formalization than bureaucracies. Of interest, according to the results in Table 4a, firms founded along commitment lines were quite similar to bureaucracies in terms of their early levels of employment formalization. ${ }^{17}$ We discuss some implications of this pattern in the Conclusion.

Consistent with the results for administrative intensity, gender composition at the end of the first year was negatively related to employment formalization, but the effect was not highly significant. Predictably, firms that had more employees at the end of the first year were significantly more likely to have adopted formalized HR practices, as were manufacturing enterprises (relative to the omitted category of computer- and telecommunications-related firms). Table 4a also indicates that firms intending to compete primarily through marketing or service-based strategies (the omitted category) formalized employment a bit more in their first year of operations than did otherwise comparable firms pursuing other strategies (particularly cost minimization), perhaps because of the key role that early employees play in establishing and maintaining relations to the firm's key customers. ${ }^{18}$

Table $4 \mathrm{~b}$ reports comparable analyses modeling the number of formalized HR practices adopted by each firm by the time it was studied in 1994-1995. Al-

16. For some models, OLS cstimates revealed the same pattern of heteroskedasticity encountered in our analyses of managerial intensity, with the error variance diminishing with firm size. In those cases, we used WLS, weighting observations as a function of 1994-1995 employment.

17. The contrast between engineering and commitment firms is statistically significant if the latter is made the omitted category in Table 4a.

18. We coded the founder's intended business strategy from responses provided in the interviews. [For a full description of the different types of strategies identified, sec Hannan, Burton, and Baron (1996)]. Our analysis includes one variable capturing firms intending to pursuc a cost strategy and another dummy variable denoting firms that intended to compete based either on technological innovation, enhancement of existing products or technologies, or by combining an emphasis on technology with a focus on customers and marketing. The omitted category represents firms intending to compete based on marketing and/or customer service. 
Table 4a. Formalization of Employment Practices in the First Year of Operations: Negative Binomial and OLS Probit Regressions ${ }^{a}$

\begin{tabular}{|c|c|c|c|c|c|c|}
\hline \multirow[b]{2}{*}{ Variable } & \multicolumn{3}{|c|}{$\begin{array}{c}\text { Count Model: Negative } \\
\text { Binomial } \\
\text { (1) }\end{array}$} & \multicolumn{3}{|c|}{$\begin{array}{l}\text { Probit-Transformed Proportion: } \\
\text { OLS } \\
\text { (2) }\end{array}$} \\
\hline & Coeff. & $Z$ & $P>|Z|$ & Coeff. & $t$ & Sig. \\
\hline Autocracy & -1.056 & -1.021 & 0.307 & -0.287 & -0.655 & 0.515 \\
\hline Commitment & -0.176 & -0.263 & 0.793 & -0.052 & -0.155 & 0.877 \\
\hline Engineering & -1.484 & -2.227 & 0.026 & -0.518 & -1.690 & 0.096 \\
\hline Star & -0.742 & -0.780 & 0.435 & -0.356 & -0.919 & 0.362 \\
\hline Hybrid & -0.410 & -0.681 & 0.496 & -0.213 & -0.707 & 0.482 \\
\hline Year 1 employment (In) & 0.419 & 2.629 & 0.009 & 0.183 & 2.590 & 0.012 \\
\hline Cost strategy & -1.168 & -1.389 & 0.165 & -0.805 & -0.198 & 0.052 \\
\hline $\begin{array}{l}\text { Enhancer, marketing, or } \\
\text { hybrid strategy }\end{array}$ & -0.487 & -1.026 & 0.305 & -0.387 & -1.823 & 0.073 \\
\hline Manufacturing ${ }^{b}$ & 1.556 & 2.361 & 0.018 & 1.036 & 3.161 & 0.002 \\
\hline Research $b$ & -0.272 & -0.201 & 0.840 & 0.074 & 0.174 & 0.862 \\
\hline Medical/biotech $b$ & -0.504 & -0.742 & 0.458 & -0.047 & -0.210 & 0.834 \\
\hline Year 1 percent female & -1.927 & -1.525 & 0.127 & -0.930 & -1.709 & 0.092 \\
\hline Missing data adjustment & -0.010 & -0.101 & 0.919 & & & \\
\hline Constant & 0.320 & 0.408 & 0.683 & -0.939 & -2.465 & 0.016 \\
\hline Overdispersion ( $\alpha$ ) & \multicolumn{3}{|l|}{$0.655^{c}$} & & & \\
\hline Mean of dep. var. & \multicolumn{3}{|c|}{1.195} & \multicolumn{3}{|c|}{-1.256} \\
\hline $\begin{array}{l}\text { Std. deviation of } \\
\text { dep. var }\end{array}$ & \multicolumn{3}{|c|}{$\begin{array}{c}1.899 \\
\chi^{2}=27.37(13) ; p=.011 \\
\text { Log likelihood }=-100.218 \\
\text { Pseudo } R^{2}=0.120\end{array}$} & \multicolumn{3}{|c|}{$\begin{array}{c}0.648 \\
R^{2}=0.373 ; p=.001 \\
\text { Adjusted } R^{2}=0.256 \\
\text { SEE }=0.559\end{array}$} \\
\hline
\end{tabular}

${ }^{a} N=77$. Negative binomial regression predicts the number of formalized HR practices adopted by end of first year OLS analysis predicts the (probit-transformed) proportion of the $11 \mathrm{HR}$ practices adopted during first year of operations: dependent variable is probit $[N /(11-M)]$, where $N$ is the number of HR practices adopted during the first year and $M$ is the number of practices for which data on timing of adoption were missing. Negative binomial model includes a control for $M$ (i.e.. "missing data adjustment"). Results based on unweighted data.

$b$ Omitted industry category represents computer hardware and software, semiconductor devices, and telecommunications and networking equipment.

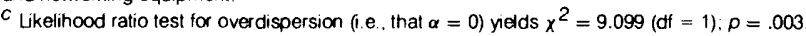

though commitment firms now display less employment formalization than all other types, the differences across organizational models are small and far from statistically significant. ${ }^{19}$ The strongest predictors of employment formalization in 1994-1995 include employment growth (which increases formalization); pursuing a technology-based or hybrid technology-marketing strategy (which

19. If commitment is specified as the omitted category, the contrast between autocracy and commitment is significant at the .001 level $(t=3.410)$; no other contrast is significant cven at the .10 level. 
reduces formalization); having received venture capital (which increases employment formalization); and organizational age (which increases formalization). These effects are evident after controlling (in model 3) for the level of employment formalization evident at the end of the first year of operations.

Unexpectedly, Table $4 \mathrm{~b}$ indicates that firms with a higher percentage of female employees in year 1 subsequently adopted more formalized employment practices (see model 3 ). This effect is consistent with prior research demonstrating that the proportionate representation of women in organizations is a determinant of changes that promote equity in job assignment and reward allocation (e.g., Baron, Mittman, and Newman, 1991). Table $4 \mathrm{~b}$ also indicates that having gone public is associated with less employment formalization. However, we hasten to note that neither of these unexpected effects is statistically significant in supplementary analyses of employment formalization using count models rather than conventional regression methods (available from authors on request), whereas the pattern of results is unchanged in all other respects. Furthermore, neither of these effects is replicated in dynamic analyses that use event-history methods to trace the time path of changes in employment formalization (see below). Consequently we are not inclined to place great weight on these specific anomalous findings. ${ }^{20}$

In work in progress, we are extending these analyses by exploiting information on the timing of events to gain a better understanding of the causal processes involved. Here we briefly summarize some preliminary results pertaining to employment formalization (details available from the authors on request). We analyzed a monthly "split spell" file built using information on the month and year in which each of the 11 HR practices comprising our index of employment formalization was adopted (if ever). We estimated the effects of the various covariates on the instantaneous rate of adding practices, $r_{k}(t)$, using a piecewise-exponential specification:

$r_{k}(t)=\exp \left[\gamma_{p}+\mathbf{B}^{\prime} \mathbf{X}_{t}\right]$

where $\gamma_{p}$ includes duration-period effects, $\mathbf{X}_{t}$ is a vector of independent variables (that can vary over time), and $B$ represents the parameters to be estimated. ${ }^{21}$ This kind of analysis differs in several ways from the analyses just discussed. In addition to focusing on rates of adoption (rather than the total count of practices adopted over some period), it controls for the number of practices adopted at the start of each monthly spell and uses information on changes within the study period for some covariates. Employment size is updated yearly, based on information collected from secondary sources (e.g., commercial publications

20. Furthermore, going public has no net effect when added by itself to the specification in model 1 of Table $4 \mathrm{~b}$, whereas employment growth, venture capital, and age cach has an effect similar to those shown in model 2 when added individually to model 1.

21. All results discussed in this article werc obtained from specifications that defined the duration periods as 0-12 months, 13-24 months, 25-48 months, and spclls for firms in their 49th month or beyond. We experimented with numerous other ways of specifying duration dependence, but the results were invariant. 
Table 4b. Formalization of Employment Relations in 1994-1995a

\begin{tabular}{|c|c|c|c|c|c|c|c|c|c|}
\hline \multirow[b]{2}{*}{ Variable } & \multicolumn{3}{|c|}{ Model 1} & \multicolumn{3}{|c|}{ Model 2} & \multicolumn{3}{|c|}{ Model 3} \\
\hline & Coeff. & $t$ & Sig. & Coeff. & $t$ & Sig. & Coeff. & $t$ & Sig. \\
\hline Constant & 0.061 & 0.142 & 0.888 & -0.496 & -1.273 & 0.208 & 0.002 & 0.008 & 0.994 \\
\hline Autocracy & 0.406 & 0.903 & 0.370 & 0.348 & 0.959 & 0.342 & 0.278 & 1.030 & 0.308 \\
\hline Commitment & -0.048 & -0.127 & 0.899 & -0.015 & -0.047 & 0.962 & -0.243 & -0.990 & 0.327 \\
\hline Engineering & -0.251 & -0.719 & 0.475 & -0.218 & -0.747 & 0.458 & -0.179 & -0.777 & 0.441 \\
\hline Star & -0.108 & -0.262 & 0.794 & 0.087 & 0.228 & 0.820 & 0.062 & 0.211 & 0.834 \\
\hline Hybrid & 0.222 & 0.657 & 0.514 & 0.034 & 0.113 & 0.911 & -0.116 & -0.479 & 0.634 \\
\hline \multicolumn{10}{|l|}{ Year 1 employment } \\
\hline$(\ln )$ & -0.005 & -0.069 & 0.946 & 0.154 & 2.278 & 0.027 & 0.002 & 0.027 & 0.978 \\
\hline $\begin{array}{l}\text { Cost strategy } \\
\text { Enhancer, innovator, }\end{array}$ & -0.504 & -1.112 & 0.270 & -0.676 & -1.348 & 0.183 & -0.589 & -1.282 & 0.205 \\
\hline or hybrid strategy & -0.058 & -0.272 & 0.786 & -0.335 & -2.230 & 0.030 & -0.203 & -1.934 & 0.058 \\
\hline Manufacturing ${ }^{b}$ & -0.208 & -0.501 & 0.618 & 0.156 & 0.356 & 0.723 & -0.379 & -0.876 & 0.385 \\
\hline Research ${ }^{b}$ & -0.899 & -1.789 & 0.079 & -0.702 & -1.512 & 0.136 & -0.590 & -1.476 & 0.146 \\
\hline Medical/biotech ${ }^{b}$ & 0.290 & 1.296 & 0.200 & 0.215 & 1.220 & 0.228 & 0.119 & 0.947 & 0.348 \\
\hline \multicolumn{10}{|l|}{ Year 1 percent } \\
\hline & & & & & & & & & \\
\hline
\end{tabular}


Table 4b. Continued

\begin{tabular}{|c|c|c|c|c|c|c|c|c|c|}
\hline \multirow[b]{2}{*}{ Variable } & \multicolumn{3}{|c|}{ Model 1} & \multicolumn{3}{|c|}{ Model 2} & \multicolumn{3}{|c|}{ Model 3} \\
\hline & Coeff. & $t$ & Sig. & Coeff. & $t$ & Sig. & Coeff. & $t$ & Sig. \\
\hline \multicolumn{10}{|l|}{ Employment } \\
\hline growth (\%) & & & & 0.010 & 4.857 & 0.000 & 0.010 & 6.390 & 0.000 \\
\hline \multicolumn{10}{|l|}{ Received venture } \\
\hline capital & & & & 0.346 & 2.389 & 0.020 & 0.492 & 5.158 & 0.000 \\
\hline Went public & & & & -0.433 & -2.950 & 0.005 & -0.408 & -3.638 & 0.001 \\
\hline \multicolumn{10}{|l|}{ Organizational } \\
\hline age & & & & 0.053 & 1.955 & 0.056 & 0.084 & 3.755 & 0.000 \\
\hline \multicolumn{10}{|l|}{ Year 1 formalization } \\
\hline (probit-transformed) & & & & & & & 0.444 & 4.950 & 0.000 \\
\hline Mean of dep. var. & & 0.179 & & & 0.154 & & & 0.154 & \\
\hline \multicolumn{10}{|l|}{ Std. dev. of } \\
\hline dep. var. & & 0.670 & & & 0.657 & & & 0.657 & \\
\hline$R^{2}$ & & 0.330 & 0.007 & & 0.727 & $<0.001$ & & 0.902 & $<0.001$ \\
\hline Adj. $R^{2}$ & & 0.203 & & & 0.339 & 0.647 & & 0.872 & \\
\hline$N$ of cases & & 76 & & & 72 & & & 72 & \\
\hline
\end{tabular}

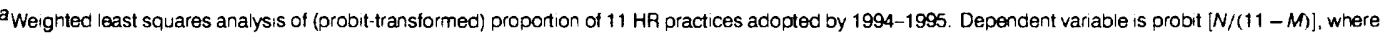
$N$ is the number of $\mathrm{HR}$ practices adopted and $M$ is the number of practices for which data on timing of adoption were missing. Modeis are weighted as a function of 1994-1995 employment, to correct for heteroskedasticity. Descriptive statistics for each model are based on unweighted data.

b Omitted industry category represents computer hardware and software, semiconductor devices, and telecommunications and networking equipment. 
listing technology companies); however, these data give only rough approximations of the time paths of changes in firm size. The event of going public is also represented as a time-varying covariate, set to zero for months in which a firm is not yet a public company and set to one for months following an IPO. The event of ever securing venture capital (VC) financing is represented in the same way. This enables us to pinpoint whether any observed associations between those events and employment formalization reflect a causal impact of becoming a public company and/or securing VC backing on the subsequent rate of bureaucratization.

Preliminary results from these dynamic analyses differ in several respects from the probit and event-count regression summarized in Tables $4 a$ and $4 b$. First, we find only one employment model effect: in a model that controls for the number of HR practices previously adopted at the start of each monthly spell, we find that firms founded along commitment model lines add employment practices at a somewhat lower rate than firms whose founders espoused other models $(b=-0.760, t=-2.10)$. This coefficient implies that the rate of formalization in commitment firms is $e^{-0.760}=47 \%$ that of otherwise identical firms founded along bureaucratic lines. However, this effect is only evident after we control for the number of HR practices each firm had in place at the start of a spell. Recall from Table $4 a$ that firms with commitment-model founders had by the end of the first year adopted about the same number of HR practices as firms with bureaucratic-model founders and more practices than firms whose founders espoused other models (particularly, the engineering blueprint), suggesting more extensive early organization building. Thus, relative to firms that began with autocratic, engineering, star, or hybrid models, firms founded along commitment-model lines apparently tend to adopt more HR practices initially and then subsequently formalize employment practices at a somewhat slower rate. $^{22}$

As in Table $4 b$, the event-history analyses reveal a positive effect of venture capital financing, confirming that firms formalize employment practices at a significantly faster rate after receiving $\mathrm{VC}$ backing. However, the results for going public differ from those in Table $4 \mathrm{~b}$ (which revealed an unexpected negative effect of having gone public). Instead, the event-history analyses reveal no net effect of a firm's currently being a public company on the rate of employment formalization. Consequently, the negative association in Table $4 \mathrm{~b}$ between having gone public and the total number of HR practices adopted by 1994-1995 presumably reflects a tendency for firms with extensive formaliza-

22. In the event-history analyses, the rate does fall with the number of prior practices adopted, due to the ceiling effect (i.e., a firm can only adopt a maximum of 11 particular HR practices in our analyses). However, the rate of adding formal HR practices docs not appear to vary with age, according to the event-history results. Note that this result is not inconsistent with the finding (in Table $4 \mathrm{~b}$ ) that organizational age has a positive effect on the total number of HR practices adopted by 1994-1995. Obviously, even if the rate of adoption is constant with age, the total number of adoptions resulting from a constant-rate process will increase with the length of the period over which organizations are observed, resulting in an association between age and the total number of practices adopted. 
tion to go public less rapidly than those with less elaborated formal practices. Perhaps firms contemplating going public resist (or delay) formalizing employment practices out of concern for having to disclose their policies to potential investors, particularly insofar as such disclosure could also increase the likelihood of sensitive HR information falling into the hands of competitors. We plan to investigate this issue in future work. It should be noted that controlling for time-varying measures of whether firms have gone public and/or received VC financing weakens the contrast between commitment and bureaucracy model firms in the rate of formalization considerably $(b=-0.590, t=-1.61)$.

In sum, early differences in the overall extent of employment formalization, reflecting founders' organization blueprints, are essentially absent after a period that averages about 6 years in our sample. ${ }^{23}$ This suggests a pattern of convergence rather than path-dependent development, as we found for managerial intensity. Event-history analyses suggest that it is not primarily a matter of how much, but rather how fast, technology companies adopt various standard HR practices designed to formalize and routinize employment relations. In particular, commitment model firms resemble firms founded along bureaucratic lines in doing somewhat more extensive organization building early on. However, commitment-model firms are subsequently somewhat slower to formalize, presumably reflecting the capacity for self-organizing and self-managing that such firms seek to cultivate. On balance, however, we find less evidence of enduring effects of founders' models on the extent or pace of employment formalization than we did on the evolution of managerial-administrative intensity. Consistent with institutional accounts that view the venture capital community as a key influence on organizational forms in the high technology sector (Suchman, 1994), receiving VC accelerates the rate at which firms in our sample formalize their employment systems.

4.3.2 Formalization and Specialization of Top Management Roles. To explore another facet of the evolution of nascent bureaucracy, we examined the extent to which specialized and formalized roles emerged within the top management groups in our sample of technology companies. In some start-ups, clear jurisdictional distinctions are evident from the outset, reflected in a formal organizational structure and specialized managerial roles demarcating areas of expertise and authority (e.g., VP for Finance, VP for Operations, etc.). Other young start-ups display minimal structural and functional differentiation within the top management cadre (except perhaps for titles that may be mandated by

23. The absence of strong relationships between founders' model and the presence of formalized HR practices in 1994-1995 should help allay methodological concerns about retrospective biases clouding our results. Recall that we obtained interview responses from founders and CEOs in 1994-1995, which were used to characterize their organizational models. If respondents were simply rationalizing what was in place within their organizations, we might have expected a stronger relationship between our typology of models and the prevalence of formal, bureaucratic HR practices in 1994-1995 than at the end of the first year of operations, whereas we found just the opposite. 
virtue of going public), and not much vertical differentiation (e.g., use of Executive or Senior Vice President titles above Vice President).

For summary purposes, we focus here on the overall extent of horizontal and vertical proliferation of management titles (a) at the end of the first year of operations, and (b) at the time the firm was interviewed by our research team in 1994-1995. Specifically we counted how many of the following categories were represented by job titles held by individuals in the firm at each time point: President; Chief Executive Officer; Chief Operating Officer; Chief Financial Officer; Chief Technical Officer; Chief Information Officer; Vice President, Engineering (R\&D, Technology); Vice President, Sales; Vice President, Marketing; Vice President, Customer Support/Service; Vice President, Operations (Manufacturing, Production); Vice President, Finance; Vice President, Administration; Vice President, Human Resources; Vice President, Strategic Planning (Business Development); and/or "Senior" or "Executive" titles in any of the vice presidential areas. ${ }^{24}$

It is not uncommon for founders in the early years to hold multiple titles, particularly such combinations as Chief Financial Officer and Vice President of Administration. To guard against such double counting, we estimated versions of our measures that excluded the first six titles in the list above-President and Chief titles - which were the ones generally held in conjunction with other titles. ${ }^{25}$ The resulting count variables capture the number of these functional and rank specializations represented within each firm's top management at each time point. As we did in measuring employment formalization, we used several different methods of analysis: we measured the proportion of possible titles represented within each firm at each time point, analyzing a probit-transformed version of that proportion using weighted least squares, and we estimated negative binomial and Poisson regression models of the raw counts of titles. These various analyses related senior management title proliferation to founders' organizational models, controlling for industry and strategy; size, gender mix, and occupational composition of the workforce; and, in models for 1994-1995, organizational age, executive succession (change in CEO), and whether the firm went public and/or received venture financing. Table 5 reports results from the

24. The information we used to measure proliferation of senior management titles provides the date at which the first management title in each category was added to the organization. This enables us to assess how many of the functional and rank distinctions were present within the top management cadre at the two points of time. Admittedly this is not necessarily the same thing as a measurc of the total number of titles being used or the magnitude of the functional and rank specialization that existed. We intend to pursue those issues in subsequent work.

25. Also, we discovered cases in which a Vice President of Sales and a Vice President of Marketing were shown as joining the top management team at the same exact point in time. We were concerned that instances of one person joining the organization as Vice President of Sales and Marketing may inadvertently have been coded as two different titles being added. Consequently we constructed versions of our measure of title proliferation that subtracted such potential occurrences of double counting (sec footnote to Table 5). Happily, our results are generally invariant with respect to whether or not such corrections are made and whether or not we include the President and Chief titles in constructing our measures of senior title proliferation. 
count models; the probit regression results (available on request from the authors) were in general slightly weaker but not materially different from those reported in Table 5.

Column 1 reports estimates from a model predicting the number of senior managerial titles at the end of the first year, and columns 2 through 4 report various models predicting proliferation of senior management titles in 1994 1995. The effects of founders' organizational models are fairly modest in Table 5. At the end of the first year of operations, there are no significant differences in title proliferation as a function of employment model. As was true for formalization of employment practices, firms founded along commitment lines were actually among the most specialized in terms of top management roles at the end of their first year, suggesting more extensive organization building, but the effect is not statistically significant after controlling for scale, industry, strategy, and initial gender mix.

Table 5 reveals a significant negative effect of initial gender mix on title proliferation in the first year of operations; firms with a larger proportion of women at the end of the first year also had much less extensive systems of management titles early on. Columns 2-4 of Table 5 provide no evidence of an enduring effect of initial gender mix on title proliferation. However, supplementary analyses using the same event history framework as was described above for employment formalization reveal a significant negative effect of the firm's initial gender mix on the rate of title proliferation $(b=-1.25, t=-2.54)$. This effect implies that a firm with $25 \%$ female employees in the first year (close to the average in our sample) proliferated specialized roles for top management at a rate equal to $e^{(-1.25 \times 0.25)}=73 \%$ of the rate for an otherwise identical company having no female employees in the first year. This apparent negative relationship between initial gender mix and the structure of top management titles-both the level at the end of the first year of operations (column 1) and the rate of proliferation subsequently-is consistent with the view that organizations in which women predominate are structured less hierarchically (Martin, Knopoff, and Beckman, 1998). The result may also simply reflect a tendency for the architects of organizations to proliferate more specialized senior titles and ranks, which serve to demarcate status and create promotion ladders, in settings where men initially predominate than when women are heavily represented (see Baron, Davis-Blake, and Bielby, 1986).

According to Table 5, founders' employment models do predict the structure of senior management titles in 1994-1995, but only after controlling for differences in growth, age, going public, receiving venture capital, and age (cf. models 2 and 3 in Table 5). As expected, firms founded along bureaucratic lines develop more elaborate systems of senior management titles than other firms, especially those founded along commitment lines. The contrasts among models (particularly autocracy versus bureaucracy) become even stronger if we analyze a model of change in title proliferation by controlling for titles in year 1 (see column 4). This pattern of results is suggestive of an enduring effect of founding conditions on organizational design, inasmuch as the effects of the founders' model are manifested only with the passage of time and after controlling for initial levels of proliferation and for differences in employment 
Table 5. The Proliferation of Senior Management Titles ${ }^{a}$

\begin{tabular}{|c|c|c|c|c|c|c|c|c|c|c|c|c|}
\hline \multirow[b]{2}{*}{ Variable } & \multicolumn{3}{|c|}{$\begin{array}{l}\text { End of First Year of Operations } \\
\text { (1) }\end{array}$} & \multicolumn{3}{|c|}{ (2) } & \multicolumn{3}{|c|}{$\begin{array}{l}1994-5 \\
(3)\end{array}$} & \multicolumn{3}{|c|}{ (4) } \\
\hline & Coeff. & $z$ & $P>|z|$ & Coeff. & $z$ & $P>(z)$ & Coeff. & $z$ & $P>(z)$ & Coeff. & $z$ & $P>(z)$ \\
\hline Constant & -0.902 & -1.361 & 0.173 & 0.995 & 1.948 & 0.051 & 0.720 & 1.809 & 0.070 & 0.661 & 1.621 & 0.105 \\
\hline Autocracy & 0.747 & 1.040 & 0.298 & 0.053 & 0.095 & 0.924 & -0.612 & -1.535 & 0.125 & -1.175 & -2.683 & 0.007 \\
\hline Commitment & 0.587 & 1.016 & 0.310 & -0.098 & -0.235 & 0.814 & -0.622 & -1.996 & 0.046 & -0.797 & -2.515 & 0.012 \\
\hline Engineering & 0.241 & 0.441 & 0.659 & -0.116 & -0.315 & 0.753 & -0.393 & -1.514 & 0.130 & -0.431 & -1.668 & 0.095 \\
\hline Hybrid & -0.014 & -0.026 & 0.980 & -0.132 & -0.360 & 0.718 & -0.572 & -2.150 & 0.032 & -0.577 & -2.161 & 0.031 \\
\hline Star & 0.399 & 0.582 & 0.560 & -0.048 & -0.102 & 0.919 & -0.526 & -1.407 & 0.159 & -0.536 & -1.464 & 0.143 \\
\hline Year 1 employment $(\mathbf{I n})$ & 0.505 & 4.377 & 0.000 & 0.163 & 1.801 & 0.072 & 0.127 & 1.518 & 0.129 & -0.003 & -0.035 & 0.972 \\
\hline Cost strategy & -1.977 & -1.733 & 0.083 & -0.809 & -1.151 & 0.250 & -15.245 & -0.023 & 0.982 & -14.918 & -0.023 & 0.982 \\
\hline $\begin{array}{l}\text { Enhancer, innovator, or } \\
\text { hybrid strategy }\end{array}$ & 0.026 & 0.066 & 0.947 & 0.333 & 1.129 & 0.259 & 0.158 & 0.727 & 0.467 & 0.171 & 0.786 & 0.432 \\
\hline Manufacturing ${ }^{b}$ & -0.508 & -0.648 & 0.517 & -1.185 & -1.932 & 0.053 & -0.513 & -0.835 & 0.404 & -0.335 & -0.543 & 0.587 \\
\hline Research ${ }^{b}$ & -0.219 & -0.279 & 0.780 & -1.540 & -1.877 & 0.060 & -0.970 & -1.313 & 0.189 & -1.047 & -1.418 & 0.156 \\
\hline Medical/biotech ${ }^{b}$ & -0.460 & -0.965 & 0.334 & -0.135 & -0.484 & 0.628 & -0.388 & -1.775 & 0.076 & -0.329 & -1.547 & 0.122 \\
\hline Year 1 percent female & -2.387 & -2.248 & 0.025 & -0.470 & -0.655 & 0.512 & -0.593 & -1.106 & 0.269 & 0.020 & 0.036 & 0.971 \\
\hline
\end{tabular}




\begin{tabular}{|c|c|c|c|c|c|c|c|c|c|c|c|c|}
\hline \multirow[b]{2}{*}{ Variable } & \multicolumn{3}{|c|}{$\begin{array}{l}\text { End of First Year of Operations } \\
\text { (1) }\end{array}$} & \multicolumn{6}{|c|}{ (2) } & \multicolumn{3}{|c|}{ (4) } \\
\hline & Coeff. & $z$ & $P>|z|$ & Coeff. & $z$ & $P>(Z)$ & Coeff. & $z$ & $P>(z)$ & Coeff. & $z$ & $P>(z)$ \\
\hline Employment growth (\%) & & & & & & & 0.007 & 2.289 & 0.022 & 0.007 & 2.459 & 0.014 \\
\hline Received venture capital & & & & & & & 0.328 & 1.587 & 0.112 & 0.345 & 1.661 & 0.097 \\
\hline Went public & & & & & & & 0.663 & 4.353 & 0.000 & 0.581 & 3.770 & 0.000 \\
\hline Organizational age & & & & & & & 0.046 & 1.665 & 0.096 & 0.055 & 1.944 & 0.052 \\
\hline Year 1 senior mgmt. titles & & & & & & & & & & 0.190 & 3.776 & 0.000 \\
\hline Overdispersion $(\alpha)$ & $o^{c}$ & & & $0.253^{b}$ & & & $o^{c}$ & & & $\sigma^{c}$ & & \\
\hline Mean of dep. var. & & & & & 1.09 & & & 4.110 & & & 4.110 & \\
\hline \multirow[t]{2}{*}{ Std. dev. of dep. var. } & & & & & 3.15 & & & 3.234 & & & 3.234 & \\
\hline & \multicolumn{3}{|c|}{$\begin{array}{c}\chi^{2}=32.23(12) ; p=.001 \\
\text { Log likelihood }=-101.701 \\
\text { Pseudo } R^{2}=0.137 \\
N=78\end{array}$} & \multicolumn{3}{|c|}{$\begin{array}{c}\chi^{2}=22.12(12) ; p=.036 \\
\text { Log likelihood }=-180.231 \\
\text { Pseudo } R^{2}=0.058 \\
N=78\end{array}$} & \multicolumn{3}{|c|}{$\begin{array}{c}\chi^{2}=111.12(16) ; p=.000 \\
\text { Log likelihood }=-147.770 \\
\text { Pseudo } R^{2}=0.273 \\
N=73\end{array}$} & \multicolumn{3}{|c|}{$\begin{array}{c}\chi^{2}=125.77(17) ; p=.000 \\
\text { Log likelihood }=-140.443 \\
\text { Pseudo } R^{2}=0.309 \\
N=73\end{array}$} \\
\hline
\end{tabular}

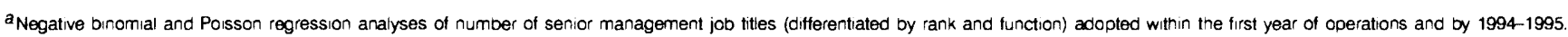
Dependent variable equals the number of titles adopted (out of 18 possible) minus an adjustment for particular titles that may have spanned more than one category, to guard against double counting

(see text for explanation). Results are unweighted.

${ }^{c}$ Likelinood ratio test of negative binomial specification against Poisson model suggested no evidence of overdispersion, so $\alpha$ is constrained to 0 (and Poisson regression results are reported). 
growth, age, going public, and the like.

However, as we found in analyzing formalization of employment policies, these enduring effects of founding conditions are relatively weak in comparison with internal and external forces that firms face during their early years of development. ${ }^{26}$ Indeed, the effects of founders' models (and of most other independent variables) on title proliferation are even weaker in models using the probit-transformed WLS regression approach employed in Table $4 \mathrm{~b}$ for employment formalization. And in supplementary event history analyses of the time path of title proliferation, we find no effect of founders' models on the rate at which firms proliferate senior management titles. ${ }^{27}$

Column 4 shows that increases in the proliferation of management titles between the first year of operations and 1994-1995 are driven by employment growth and, to a lesser extent, age, both of which (not surprisingly) increase the extent to which organizations proliferate top management specializations. Table 5 also suggests that the proliferation of specialized managerial titles is related to two formative experiences in the development of a start-up company: receiving venture financing and having gone public (but see below). These results are consistent with the claims of institutionalists that the development of bureaucratic organizational structures is attributable in part to the desire to conform to standards and expectations promulgated by external constituencies in order to appear legitimate and credible in the eyes of key stakeholders. The venture capital effect is also evident in event-history analyses; firms proliferate senior management roles at a significantly faster rate after having received VC funding, a pattern which is consistent with the conventional wisdom that a major role played by venture capitalists involves leveraging their networks and experience to assist start-ups in staffing key executive positions. However, as was true in the event-history analyses of employment formalization, we do not find any causal effect of becoming a public company on the rate of title proliferation; indeed, in the event history models, the effect is negative but not significant. This suggests that the positive association between going public and proliferating senior management titles (evident in Table 5) may arise because firms are creating specialized roles to flesh out their top management teams prior to going public, a possibility we intend to examine in future work by analyzing the arrival rates of particular managerial roles (e.g., CFO,

26. In fact, if the five employment model variables are omitted from the model in column 4 of Table 5, the difference in $\chi^{2}$ is 9.485 ( $\left.\mathrm{df}=5\right)$, which is only marginally significant $(p=.091)$. In contrast, omitting growth, age, venture capital, and going public from the model in column 4 reduces $\chi^{2}$ by $48.407(\mathrm{df}=4)$, with a $p$ valuc of less than one in a billion. It should be noted that the available $N$ is reduced from 78 to 73 when the latter four variables are included (cf. models 2 and 3 in Table 5). The results shown in Table 5 are unchanged if model 2 is estimated on the same 73 cases analyzed in columns 3 and 4 . The large difference in the coefficient for the cost strategy variable reflects the fact that this strategy is rare in the sample, and the drop in sample size from 78 in column 2 to 73 in column 3 happens to omit several of the firms employing that strategy, resulting in very little variation on that measure.

27. The rate of adding titles does decrease significantly with age, however. As noted above (footnote 22), this result does not contradict the finding (in Table 5) of a positive association between completed age and the total number of titles adopted by 1994-1995. 
Director of HR) and how these coincide with other events (including going public).

\section{Discussion: Implications for Theory and Research on Bureaucracy}

We have examined how founders' conceptions of the employment relation and the social make-up of an organization at its inception shape three facets of bureaucratization: the size of the managerial and administrative component, formalization of employment relations, and the emergence of specialized top management roles. We found a particularly strong and robust enduring imprint of founding conditions on managerial-administrative intensity. Bearing in mind that the typical firm in our sample was roughly only 6 years old at the time it was studied (the interquartile range is 3.8 to 8.2 years), the different developmental paths down which founders steered their new enterprises seem rapidly to have led to marked differences in their reliance on specialized managerial and administrative roles to control and coordinate activity.

We found some evidence suggesting similar effects of founders' models on the formalization of employment relations and on the proliferation of senior management titles. Firms founded along bureaucratic versus commitment lines tended to be at opposite extremes in terms of the propensity to formalize employment practices and specialize roles within the senior management ranks. However, the imprint of founders' blueprints seems considerably stronger, more consistent, and more robust on managerial-administrative intensity than on employment formalization and title proliferation, where the effects not only were weaker statistically but also typically depended on the particular dependent variable, statistical technique, and model specification employed. Our analyses suggest that the amount and rate of employment formalization and senior management title proliferation were shaped more by scale and growth, organizational aging, and the influence of key external constituents, particularly venture capitalists (who had no discernible effect on the tendency of firms to add managerial-administrative overhead).

We believe this pattern of results has some important implications for theory and research on bureaucracy and on processes of path-dependent organizational development. Before discussing those issues, however, we note some limitations of this work and some potential dangers in generalizing from this sample to other organizational populations. The type of study we have undertaken, tracing firms forward from their infancy through a combination of archival data and field work, is inherently messy. Moreover, although our study is certainly less prone to survivor biases of the sort that plague studies of bureaucratization based on long-lived samples of organizations, surely a process of selection governs whether organizations ever leave a sufficient trail to become at risk of inclusion in our study in the first place. And in a world of unlimited time, resources, and access, it would clearly be desirable to gather contemporaneous, rather than retrospective, information about the assumptions and intentions of organizational architects, as well as gathering information from organizational participants that would enable one to compare the founders' conceptions and formal policies on the one hand with what organizational members perceive 
on the other hand. To be sure, in the trade-off between breadth and depth we have sacrificed some depth out of a conviction that there are already many more rich case studies of entrepreneurial ventures in existence than there are comprehensive databases against which hypotheses can be tested.

Another question that might be raised is whether demonstrating an enduring imprint of founding conditions on technology companies that are almost all still in their first decade is very powerful evidence of path dependence. The issue, we believe, is an empirical one that remains to be examined in subsequent research. As Hannan and Freeman (1984) noted in discussing the tendency toward structural inertia in organizations, one must assess the rate and direction of organizational change relative to trends in the relevant environment(s) within which the population of organizations being studied operate. Demonstrating strong tendencies toward path-dependent development in the evolution of religious organizations, for instance, would presumable carry little shock value, given the mission and environment of a typical church. In contrast, we contend that the organizations examined in this article-nascent technology companies in Silicon Valley-are subject in their early years to very turbulent environments, intense product and labor market competition, strong selection pressures, and numerous influences that should encourage structural isomorphism.

Consequently, we believe the evidence of path-dependent development of organizational forms reported here is substantively significant. Given the abovenoted limitations of our study, we do not want to overreach in sketching some implications of this work. At the same time, we believe our results have some intriguing and important implications for theory and research concerning organizational forms. In this section, we suggest some potentially fruitful avenues for theory development and empirical research in studying organization-building in general and the forms, determinants, and consequences of bureaucratization in particular.

\subsection{Bureaucracy: Form versus Substance}

Organizational sociologists of the neo-institutional school have argued that formal structures, including many of the taken-for-granted features of modern bureaucracies, are adopted by organizations with an eye toward external constituents and a desire to signal legitimacy rather than because of a clear or compelling technical rationale (e.g., Tolbert and Zucker, 1983; Scott, 1995). Some of our findings may be read as supporting that view. For instance, we found that formalization of employment policies and the proliferation of top management specialties were fueled by growth, aging, having received venture capital, and/or by having gone public. These results - especially the event history findings showing that receiving venture capital increases the rate of employment formalization and title proliferation-are consistent with accounts emphasizing the need for young organizations to develop "appropriate" organizational forms as they grow and age to convince valuable external stakeholders of their worthiness (e.g., Suchman, 1994). Those effects dwarfed the effects of founders' employment blueprints.

We think this is an intriguing pattern of results. Apparently, founders' 
premises regarding employment relations and organizational concerns have only limited enduring impact on the more superficial facets of bureaucracy that have preoccupied neo-institutionalists, such as adoption of standard HR policies and creation of specialized managerial job titles. Yet we find much more dramatic evidence of imprinting in the effects of founders' models on the actual amount of specialized managerial-administrative personnel employed in a firm of a given size; roughly 6 years after founding (on average), bureaucratic versus commitment model firms differ markedly in the extent to which they actually rely on bureaucrats (managerial and administrative specialists) to coordinate and control activities (see Table 3 ). This suggests to us that the neo-institutionalists have it right when they suggest that many of the surface trappings of modern bureaucracies are adopted to satisfy external constituents (such as venture capitalists and the constituencies of public corporations), reflecting a loose coupling between those features and the organizational "core" (Meyer and Rowan, 1977). But what some neo-institutional accounts miss is the fact that founders' models also serve to institutionalize an abiding orientation toward coordination and control, reflected in the propensity to rely on selfmanagement versus specialized overhead personnel as organizations become larger, older, and more complex.

Hence there may not be a contradiction between the conception of organizational evolution as path dependent and the view that organizations adapt and evolve in order to meet the material and symbolic needs imposed by their environments. Rather, cultural, cognitive, and institutional forces may have both kinds of effects. Founders' models, which represent cultural prescriptions for organizing, shape the assumptions, fundamental orientations, and capabilities of organizational members, creating strong path dependence in the extent to which "management and administration" becomes defined as a specialty versus a collective responsibility. At the same time, cultural and institutional forces exert continuing pressure on organizations to adapt and evolve in ways that signal and symbolize appropriate messages to the environment, and these pressures produce the more superficial, surface innovations and changes that have been the focus of most neo-institutional scholarship.

This suggests that it may be useful to distinguish between bureaucracy as a set of phenotypic characteristics of organizations and bureaucracy as a genotype, which is programmed during infancy. Institutionalists have wanted to claim credit for both, invoking cultural forces to explain both stability and change, organizational diversity and uniformity [for a discussion, see the papers in Powell and DiMaggio (1991)]. They will be justified in doing so, however, only insofar as they can specify and operationalize the blueprints or genotypes that dictate the varied developmental paths that particular organizations follow.

\subsection{Conceptualizing and Measuring Organizational Models}

5.2.1 Where Do Models Come From? If organizational architects impose their mental models on the enterprises they design, leaving an indelible imprint, this raises the obvious question of where those models come from. Within the limits of the data available to us, we are currently exploring that issue within 
this sample. We suspect that efforts to understand where founding models come from will benefit from attending to three sets of factors. The first is the stock of social capital on which the founders can draw, by virtue of their prior work experiences, connections to labor market institutions (e.g., universities, competitors), and social networks (see Granovetter, 1995). Within our sample, the commitment (and possibly the star) model seems to stand at one extreme in terms of presuming a fairly high degree of connectedness among actors early in the history of the enterprise. Early employees may be recruited through social networks of the founders (based on shared ascriptive characteristics or on educational, occupational, and other ties), and-as we noted in describing the effects of gender composition on managerial intensity and formalization of HR policies - this in turn may enable the firm over time to rely less on formal modes of control.

At the other extreme, the bureaucratic model seems to presume the least connectedness among the founders and in their relations with employees. Hence we would expect to see this model adopted more frequently in foundings that emerged as arms-length transactions between heretofore unconnected parties, perhaps brokered by third-party intermediaries (such as venture capitalists-see below), and in foundings initiated by individuals who are not connected to the key institutions that can supply talent (specifically, educational institutions and key competitors). The engineering model is likely to lie in between these extremes. So is the autocratic model, but we suspect that its intermediate position on average will mask two subtypes which are at opposite extremes: armslength autocracies versus what we might be called "personalistic" autocracies (of which the archetype is the small dictatorial family firm).

A second set of influences likely to shape founders' models are the positions of founders in social networks, particularly ties to key gatekeepers capable of shaping or dictating organizational structure. In a sense, these social positions simply represent another form of social capital that entrepreneurs have at their disposal. Although we are skeptical about the blanket claims of isomorphism made by some sociologists of organizations, we concur with the notion that key external gatekeepers can and do play a powerful role in dictating organizational structure.

Our results suggest that the legal requirements and social expectations associated with VC backing and becoming a publicly traded company create pressures to bureaucratize and increased need to formalize employment and specialize managerial and administrative roles. Those findings seem congruent with institutional perspectives in organizational sociology, which have tended to view corporate lawyers, venture capitalists, and other gatekeepers as sources of structural isomorphism, promoting the bureaucratization of enterprise (Suchman, 1994). In the context of technology start-ups in Silicon Valley, corporate lawyers and venture capitalists expose their entrepreneur-clients to organizational and managerial prescriptions being applied in other settings, serving as additional catalysts for the diffusion of organizational forms. For instance, we know of at least one venture capital firm that convenes a regular meeting of the human resource executives from its client companies to provide an opportunity 
Table 6. Founder's Organizational Model by Whether/When Firm Received Venture Financing

Founder's Organizational Model

\begin{tabular}{lccccccc}
\cline { 3 - 4 } $\begin{array}{l}\text { Venture } \\
\text { Financing }\end{array}$ & Autocracy & Commitment & Star & Engineering & Bureaucracy & Hybrid & Total \\
\hline $\begin{array}{l}\text { None as of } \\
\quad \begin{array}{l}1994-1995 \\
\text { Received within }\end{array}\end{array}$ & 4 & 10 & 5 & 13 & 1 & 14 & 47 \\
$\quad$ first 2 years & 3 & 6 & 8 & 30 & 8 & 24 & 79 \\
$\begin{array}{l}\text { Received after } \\
\quad 2+\text { years }\end{array}$ & 2 & 4 & 1 & 5 & 0 & 8 & 20 \\
Total & 9 & 20 & 14 & 48 & 9 & 46 & 146 \\
\hline
\end{tabular}

$\chi^{2}=14.704(\mathrm{df}=10) ; p=.143$

for exchange of information and common exposure to new ideas. Or consider this excerpt from the web site of Kleiner, Perkins, Caulfield \& Byers (KPCB), one of Silicon Valley's most successful and preeminent venture capital firms:

One of the most important elements within KPCB's concept of valueadded investing is access to a network of shared information and knowledge referred to as the Keiretsu. The term "keiretsu" describes modern Japanese networks of companies linked by mutual obligation. The companies in the KPCB Keiretsu consistently share experiences, insights, knowledge and information. This networking resource, comprised of more than 175 companies and thousands of executives, has proven to be an invaluable tool to entrepreneurs in both emerging and developing companies. ${ }^{28}$

Accordingly, it is natural to ask whether venture capitalists affect directly the organizational blueprints that founders select in launching their firms. Toward that end, Table 6 provides a simple descriptive profile of organizational founding models as a function of whether and when firms received venture financing. The table shows that firms that received venture financing early in their development (within their first 2 years of normal operations) were also more likely to have been built along bureaucratic lines; indeed, all but one of the firms that were created as bureaucracies had received venture backing within their first 2 years. Conversely, the firms that received early venture money were somewhat less likely to have been founded along commitment lines (only $7.6 \%$ of the firms to receive early venture money exhibited that blueprint, compared to $21.3 \%$ of firms that had not received venture money through 1994-1995).

On the other hand, the association in Table 6 is quite weak (and not statistically significant overall at the .10 level), and weaker still if we classify firms based on having received venture financing within their first year of opera-

28. Viewable online at http://www.kpcb.com/keiretsu/index.html. 
tions (rather than using a 2-year cutoff). ${ }^{29}$ Though we have only just begun examining these data, these simple descriptive results hardly bolster theoretical stories positing that venture capitalists and similar constituents promote unitary structural isomorphism. Apparently, having an early relationship with a venture capital firm was hardly determinative of the founder's organizational blueprint. Furthermore, recall that we found no evidence that receiving venture capital influences increases in managerial intensity (i.e., the actual magnitude of bureaucratic specialists) in firms over time. Rather, the influence of venture capitalists seemed to be confined to the realm of formal structures and policies. Neo-institutionalists' arguments regarding isomorphism induced by key external gatekeepers may apply to the most superficial aspects of organizational forms and practices more than to their "hard wiring."

This suggests an intriguing alternative to the institutionalists' viewpointthat, at least with regard to more fundamental, genotypic aspects of organizational forms, these gatekeepers may actually foster increased differentiation and heterogeneity among organizational models and forms within a population. Unlike most of the entrepreneurs with whom they interact, most lawyers, financiers, consultants, and the like have been exposed to a large enough database of organizational ventures to have developed at least an implicit version of contingency theory that guides their thinking regarding appropriate organizational form. Furthermore, to stake out a viable niche within a highly competitive marketplace for business advice, these gatekeepers may need to champion approaches to entrepreneurial challenges that serve to differentiate their advice from that of competitors. This may engender a sorting process, whereby clients who are inclined to approach organizational and management issues in a particular way find support among business advisors who have a reputation for being sympathetic to that approach. (Consider the choice of a law firm to handle employment and labor matters, with firms having quite well-established reputations for how adversarial versus conciliatory they are vis-à-vis employees.) To the extent that such sorting occurs, some of the effects of these business advisors may already be captured by control variables included in our models, particularly whether the firm has gone public, with firms intending to go public securing their venture funding and legal advice early on from the sort of advisors most likely to advocate organizational designs appropriate for larger public corporations. We are currently examining these issues in greater depth. ${ }^{30}$

Another factor that deserves consideration in analyzing the origins of founders' models is what one might term competitive labor market strategy. Although sociologists have tended to emphasize the benefits of adhering to

29. Nor is the association strengthened if we include in each model category only the pure-type cases, assigning the quasi-pure cases to the residual ("other") category.

30. For instance, in collaboration with Professors Thomas Hellmann and Manju Puri of Stanford University, we have recently gathered detailed data on the financing histories of the SPEC companies, which will enable more finc-grained analyses of how financiers shape carly organizational design choices. In addition, we have also gathered information on lawyers and other advisors and business partners, whose influence we intend to assess. 
dominant organizational models within a population, in some circumstances there are presumably sound competitive reasons to do precisely the opposite. Late entrants into an industry, firms with limited resources, or firms that wish to minimize the likelihood of employees departing to competitors may be impelled to adopt organizational models that are at variance with what is standard in that sector. For instance, if one is seeking to compete with a well-established competitor that long ago embraced a commitment model, there may be real dangers in trying to emulate their blueprint. Because the competitor has already derived a first-mover advantage by screening the labor market, the new entrant faces a more acute adverse selection problem, particularly insofar as employees willing to sign on to the only (or first) commitment firm in an industry or region are signaling more useful information about themselves than are employees who are willing to sign on to the 20th commitment firm in the same setting.

Note that firms founded along commitment and star lines may be able to do a better job at retaining their valuable human assets, but of necessity they will have to be more selective. Consequently, another strategic concern that may affect the choice of model concerns the extent to which the firm anticipates the need to be open in its hiring practices, either because of the desire to import knowledge and technology from other companies or because of the expectation that the strategy will require rapid increases in the size and/or diversity of the workforce. When founders anticipate such issues of scalability, we might expect to see greater reliance on the engineering or bureaucratic model early on. The trade-off here, of course, is that these models may not involve handcuffs that are as binding on employees, but they may facilitate the firm's efforts to appropriate human assets from other sources. We believe there are some interesting opportunities for both theoretical modeling and additional empirical work along these lines.

\subsection{Varieties of Bureaucratization}

We found limited evidence that founders' blueprints had enduring effects on formalization of the employment relationship; rather, most organizations seem to evolve toward more formalized employment systems as they grow and age. Preliminary dynamic analyses, which we briefly summarized, suggest that founding conditions may exert a stronger effect on the time path of formalization than they do on the mere presence or absence of specific practices. Specifically, firms founded along commitment model lines apparently engage in somewhat more extensive organization building early on, formalizing employment relations within the first year of operations to about the same degree as firms founded along bureaucratic lines. However, having made such early investments in organization building-coupled with intensive screening, inculturation, and practices aimed at building employee loyalty-commitment model firms are able subsequently to economize on formal controls, reflected in leaner managerial-administrative structures and somewhat less additional employment formalization, consistent with claims about the virtues of "high commitment work systems."

This suggests that founding conditions may shape not only the extent of 
bureaucratization over time, but also the particular forms that bureaucratization takes, with the adoption of particular structures and practices having quite different meanings and implications in organizations that were built according to different blueprints. As firms face internal and/or external pressures to bureaucratize, how they go about formalizing and rationalizing their activities (as well as the types of sanctions used to punish rule violations) are likely to differ systematically as a function of the initial model around which the enterprise was built.

For instance, consider the issue of performance measurement. We documented that, all else being equal, firms founded along clan or commitment lines are able to economize on managerial and administrative specialists, particularly relative to firms whose founders embraced a bureaucratic model at the outset. However, commitment firms were only slightly less likely to adopt formalized employment policies. This suggests to us that the enduring effects of founders' premises may be reflected less in the extent of formalization (e.g., adoption of formal performance evaluation) than in the content and uses of particular bureaucratic policies and structures. We hypothesize, for instance, that in firms founded along commitment lines, formalization of performance evaluation will occur more along the lines of assessing compliance with prescribed organizational processes and values and be used for purposes of providing developmental feedback, so that the organization can continue to rely on self-management and informal controls in lieu of specialized managerial and administrative personnel. In contrast, we would expect formalization of performance evaluation in engineering, autocracy, and (especially) star and bureaucracy firms to involve the creation of precise outcome metrics that are used to make comparisons (and reward allocations) across individuals or subunits.

Put differently, founders' models may help explain variation in an important dimension along which bureaucratic structures and practices vary, namely, their enabling versus coercive character. Analysts of bureaucracy have noted that some efforts to formalize and rationalize organizational activity are coerciveintended to induce compliance and reduce actors' discretion - whereas others are enabling, intended to enhance and support employees' activities, insulating and protecting them from influences that might get in their way (Adler and Borys, 1996). We conjecture that the process of formalization proceeds along more coercive lines in organizations built according to autocratic or bureaucratic principles and along more enabling lines in organizations premised on a commitment model, with the star and engineering models being intermediate. How formalization evolves within firms created along star lines seems particularly difficult to predict because the experience of firms in our sample suggests there may be two distinct paths of bureaucratization in star firms. In one of those paths, formalization and rationalization are minimized due to the desire of stars to retain autonomy and control over their tasks, and rules and procedures serve primarily to protect stars from administrative interference. In the other variant, formalization and rationalization aim to level preexisting differences within the organization (i.e., between the stars and others) and impose universalistic standards of treatment and conduct, especially as the efforts of 
stars need to be coordinated and integrated more closely with the rest of the enterprise.

More broadly, our analysis suggests how and why we might expect to see differences in how legitimate authority is organized and exercised, with formal structures serving to institutionalize arrangements that existed early in the history of an enterprise. Within the population of firms we are studying, it seems plausible that founders' initial organizational models will shape the nature of legitimate authority and how it is structured as enterprises bureaucratize.

Recall that Weber's typology of organizational forms revolved around the bases for legitimating authority, distinguishing three ideal-types: charismatic, traditional, and rational-legal authority. In the pure-type bureaucracy, legitimate authority is vested in offices, not individuals. Noting that there are numerous potential bases for legitimating authority, not all of which will correspond to his pure types, Weber (1947:329) emphasizes that "the idea that the whole of concrete historical reality can be exhausted in the conceptual scheme ... is as far from the author's thoughts as anything could be." For example, Weber (1947:329) identified one potential form of legitimate authority as "the authority of status groups." Though Weber's emphasis was on status groups based on membership in social groupings or communities that produce a common life experience, the clearest parallel within our technology companies is in the project teams and occupational communities one finds in firms structured in terms of the engineering model, where status is associated with the "coolness" of the work. This leads us to conjecture that bureaucratization may take a distinctive form in engineering firms, institutionalizing the association between legitimate authority and status group membership, which is defined primarily by occupational subcultures and/or the technical sophistication and strategic importance of one's project. Here, differences in authority would attach primarily to teams or project units, with bureaucratic rules and procedures specifying the criteria of entitlement and the procedures by which conflicts over shared resources among competing units are to be resolved.

In contrast, we would expect to see legitimate authority institutionalized along other dimensions in firms that were founded according to a different implicit organizational model. Firms founded along autocratic lines might be more likely to base authority initially on closeness to the founder-leader (e.g., the founder is closest to the head of engineering, due to a preexisting personal relationship, geographical proximity, or date of entry to the organization), and that subsequently becomes institutionalized in terms of roles and responsibilities (e.g., the senior VP for engineering is the de facto head of the top management team in the absence of the CEO). As star firms bureaucratize, we would expect to see legitimate authority become institutionalized based on expertise and formal evaluations of professional standing, as occurs in academic organizations. However, expertise is more likely to be decoupled from formal roles in organizations founded along star lines for a variety of reasons (including the aversion of stars for administration). Consequently, in star contexts, we might expect to see bureaucratization take the form of specifying formal criteria by which expertise (decoupled from formal roles) will be evaluated and promulgating 
norms and rules governing exercise of influence that is not isomorphic with the organizational chart (e.g., when one physician can command a colleague to alter a procedure).

In organizations founded along commitment lines, we expect that bureaucratization will serve to institutionalize definitions of legitimate authority vested in broader collectivities, rather than in individuals or offices, based on notions of self-governance and adherence to the organization's core values. An example of this type of formalization might be the creation of formal rules and procedures (such as honor codes) that mandate when and how an employee may (must) police colleagues by filing a formal charge or complaint (e.g., regarding ethics violations). Whereas we might expect a firm founded initially along bureaucratic lines to create a specialized department or office to enforce codes of conduct, firms founded initially along commitment lines are more likely to vest authority in the peer group itself and promulgate rules, standards, and procedures aimed at self-regulation.

\subsection{Consequences of Bureaucratization}

Understanding the path-dependent nature of bureaucratization is likely to prove useful both for comprehending how and why contemporary bureaucracies vary and also for predicting how bureaucracies may respond to changing circumstances in the future. Consider, for instance, the recent waves of corporate downsizings, focused largely on managers and administrators. Many commentators have suggested that downsizings frequently prove ineffectual in the long run because they reflect a "binge and purge" process, with organizations soon adding back the overhead that they cut out during the last round of layoffs. Though few companies in our sample have undergone significant downsizings, an understanding of founders' organizational blueprints might help to predict (a) the probability of making significant managerial and administrative cuts, and (b) the likely permanence of those cuts. For instance, in organizations whose founders embraced a bureaucratic model from the inception, the propriety of specialized managerial and administrative functions is likely to get accepted more widely, deeply, and quickly than in organizations that initially embraced a commitment or star model.

A final and fundamental issue concerns the consequences of bureaucratization for organizational performance. We are gathering data in order to examine the effects of founders' organizational blueprints and early organizationbuilding activities, as well as intervening events (including going public, bureaucratization, executive succession, and other key changes), on financial and nonfinancial performance outcomes. One perspective would suggest that our findings regarding managerial-administrative intensity have no necessary implications for organizational performance. According to this line of reasoning, roughly the same aggregate amount of management and administration must be conducted in organizations of a given size. An organization must pay for this oversight one way or the other-whether it is conducted by specialists or by semiautonomous employees and/or teams-and it is not obvious whether 
specializing managerial and administrative functions increases or decreases the cost, quality, or speed of those activities.

We tend to disagree with this perspective. Recall the sheer magnitude of the differences in managerial and administrative intensity across founders' models (see Table 3). We find it hard to believe that these differences in staffing ratios do not have significant cost implications for the bottom line. To be sure, the qualitative effects of specializing managerial and administrative functions are difficult to predict ex ante; it is easy to envision circumstances in which managerial intensity could degrade the quality and speed of decision making in organization, but it is not particularly difficult to imagine contexts in which the opposite effects might obtain.

Indeed, we suspect that the effects on organizational performance of specializing managerial and administrative functions will depend on the blueprint that guided the organization's creation. For instance, star cultures tend to denigrate managerial and administrative functions, believing that talented stars should be insulated from such burdens to focus on their calling. Specializing management and administration to insulate scientific and technical stars from such burdens may be essential to attract and retain the extraordinary talent the firm requires. Consequently, we might expect at least some components of bureaucratization to exhibit stronger performance benefits (or weaker performance decrements) in star firms relative to firms built around different organizational blueprints.

More generally, this line of reasoning suggests that efforts to understand the impact of bureaucratization will benefit considerably from paying attention to the developmental path a given enterprise has traveled on the road to bureaucracy. Reactions to bureaucratic procedures and practices may depend not simply on whether they are enabling or coercive in character, but also on the assumptions and premises that guided the founding of the organization in the first place. As organizations grow and age, certain founding models may be more susceptible to being judged as capricious, inequitable, or intrusive; in particular, we speculate that this susceptibility may be higher among firms founded along autocratic, star, and (perhaps) commitment lines. Hence, the evolution of bureaucratic arrangements, which on their face appear coercive to outsiders, may instead be viewed by insiders as welcome and liberating (or vice versa).

If Weber was correct about the inevitability of bureaucratization, and if reactions to the introduction of bureaucratic policies and structures depend on the initial organizational blueprint, this may offer some insight into the widespread prevalence of the engineering model among technology firms at their founding. We have seen that internal and external forces create fairly strong pressures to formalize and bureaucratize, even in the early years of small technology companies. Scholars have noted the affinity of engineers and engineering cultures for systems and procedures (Shenhav, 1995). Consistent with that view, comparisons of the organizational models of founders versus current CEOs in our sample reveal that SPEC firms founded along engineering lines have the strongest propensity to become bureaucracies later on (Burton, Hannan, and 
Baron, 1998). Of the 22 firms that had switched to a pure bureaucracy model, according to the CEO's responses, 55\% had been founded along engineering lines and another $36 \%$ had been founded as hybrids that were intermediate between engineering and some other model. At the same time, the pure engineering model was also a fairly common "destination point" among SPEC companies that had not started out as pure engineering cultures. ${ }^{31}$ These patterns of movement highlight the fairly strong affinity or compatibility between the engineering model and other blueprints for technology companies, including the bureaucracy model. Viewed in this light, the prevalence of the engineering blueprint at founding in this population may in part reflect its malleability and robustness to the diversity of organizational transitions that a young technology company may confront in its formative years, including the transition toward bureaucracy.

\section{References}

Adler, Paul S., and Bryan Borys. 1996. "Two Types of Burcaucracy: Enabling and Coercive," 41 Administrative Science Quarterly 61-89.

Baron, James N., M. Dianc Burton, and Michael T. Hannan. 1996. "The Road Taken: The Origins and Evolution of Employment Systems in Emerging High-Technology Companies," 5 Industrial and Corporate Change 239-276.

Alison Davis-Blake, and William T. Biclby. 1986. "The Structure of Opportunity: How Promotion Ladders Vary Within and Among Organizations," 31 Administrative Science Quarterly 248-273.

Michacl T. Hannan, and M. Diane Burton. 1998. "Building the Iron Cage: Determinants of Managerial Intensity in the Early Years of Organizations," Harvard Business School Working Paper 98-064.

Brian S. Mittman, and Andrew E. Newman. 1991. "Targets of Opportunity: Organizational and Environmental Determinants of Gender Integration within the California Civil Service, 1979-1985," 96 American Journal of Sociology 1362-1401.

and Jeffrey Pfeffer. 1994. "The Social Psychology of Organizations and Incquality," 57 Social Psychology Quarterly 190-209.

Bocker, Warren. 1988. "Organizational Origins: Entreprencurial and Environmental Imprinting at the Time of Founding," in G. R. Carroll, cd., Ecological Models of Organizations. Cambridgc, MA: Ballinger, pp. 33-51.

Burton, M. Diane. 1995. "The Evolution of Employment Systems in High Technology Firms," Ph.D. dissertation, Stanford University.

Michael T. Hannan, and James N. Baron. 1998. "Employment Models in Entrepreneurial Companics," unpublished manuscript, Harvard Business School.

31. Specifically, we observed a number of firms that had been hybrids at their founding-combining engineering with another model, based on the founder's response - migrating to a pure engincering model, according to the CEO's responses to interviewers. Ten of the 14 companies that switched to the pure engincering model $(71.4 \%)$ fit that profile. In contrast, some modelsspecifically the star and commitment types-were virtually never adopted (i.c., "switched to") subsequent to the founding of the company. In other words, these latter models are not casily "reachable" from other starting points and seem to entail building commitments and expectations that are difficult to instill within an ongoing enterprise. The higher rate of movement toward the enginecring model underscores its fairly strong affinity with other blueprints, as well as with burcaucracy, suggesting perhaps that some firms that migrated over time to the pure enginecring model did so as part of an eventual transition toward bureaucracy. 
Edvinsson, Leif, and Michacl S. Malone. 1997. Intellectual Capital. New York: HarperBusiness.

Granovetter, Mark S. 1985. "Economic Action and Social Structure: The Problem of Embeddedness," 91 American Journal of Sociology 481-510.

1995. "The Economic Sociology of Firms and Entrcprencurs," in A. Portes, ed., The Economic Sociology of Immigration: Essays on Networks, Ethnicity, and Entrepreneurship. New York: Russell Sage Foundation, pp. 128-165.

Hannan, Michacl T., M. Diane Burton, and James N. Baron. 1996. "Inertia and Change in the Early Ycars: Employment Relations in Young, High-Technology Firms," 5 Industrial and Corporate Change 503-536.

Hannan, Michacl T., and John Freeman. 1984. "Structural Inertia and Organizational Change." 49 American Sociological Review 149-164.

Maddala, G. S. 1983. Limited-dependent and Qualitative Variables in Econometrics. Ncw York: Cambridge University Press.

Martin, Joanne, Kathy Knopoff, and Christine Beckman. 1998. "Secking an Alternative to Burcaucratic Impersonality and Emotional Labor: Bounded Emotionality at The Body Shop," 43 Administrative Science Quarterly 429-469.

Meyer, John W., and Brian Rowan. 1977. "Institutionalized Organizations: Formal Structure as Myth and Ceremony," 83 American Journal of Sociology 340-363.

Powell, Walter W., and Paul J. DiMaggio, eds. 1991. The New Institutionalism in Organizational Analysis. Chicago: University of Chicago Press.

Saxcnian, AnnaLcc. 1994. Regional Advantage: Culture and Competition in Silicon Valley and Route 128. Cambridge: Harvard University Press.

Scott, W. Richard. 1992. Organizations: Rational, Natural, and Open Systems, 3rd cdition. Englewood Cliffs, NJ: Prentice-Hall.

1995. Institutions and Organizations. Thousand Oaks, CA: Sage Publications.

Shenhav, Yehouda. 1995. "From Chaos to Systems: The Engincering Foundations of Organization Theory, 1879-1932," 40 Administrative Science Quarterly 557-585.

Suchman, Mark C. 1994. "On Advice of Counsel: Law Firms and Venture Capital Funds as Information Intermediarics in the Structuration of Silicon Valley." Ph.D. dissertation, Stanford University.

Tolbert, Pamela S., and Lynne G. Zucker. 1983. "Institutional Sources of Change in the Formal Structure of Organizations: The Diffusion of Civil Service Reform," 28 Administrative Science Quarterly 22-39.

Walton, Richard E. 1985. "From Control to Commitment in the Workplace," 63(2) Harvard Business Review 76-84.

Weber, Max. 1946. "Burcaucracy," in H. H. Gerth and C. Wright Mills, trans./cds., From Max Weber: Essays in Sociology. New York: Oxford University Press, pp. 196-244. 1947. The Theory of Social and Economic Organization (trans. by A. M. Henderson and Talcott Parsons). New York: Oxford University Press. 